Ruiz-Villanueva Virginia (Orcid ID: 0000-0002-0196-320X)

Bladé Ernest (Orcid ID: 0000-0003-1770-3960)

Ravazzolo Diego (Orcid ID: 0000-0001-8145-8723)

Wohl Ellen (Orcid ID: 0000-0001-7435-5013)

\title{
Characterization of wood-laden flows in rivers
}

Ruiz-Villanueva, V. ${ }^{1,}$ *; Mazzorana, B. ${ }^{2,3}$; Bladé, E. ${ }^{4}$, Bürkli, L. ${ }^{1}$; Iribarren-Anacona, P. ${ }^{2}$;

Mao, L. ${ }^{5,6}$; Nakamura, F. ${ }^{7}$; Ravazzolo, D. ${ }^{8}$, Rickenmann, D. ${ }^{9}$, Sanz-Ramos, M", Stoffel, M. ${ }^{1,10,11}$, Wohl, E. ${ }^{12}$;

*corresponding author: Virginia Ruiz-Villanueva, Virginia.ruiz@ unige.ch

${ }^{1}$ Institute for Environmental Sciences, University of Geneva, Geneva, Switzerland.

${ }^{2}$ Instituto de Ciencias de la Tierra, Faculty of Science, Universidad Austral de Chile,

Valdivia, Chile

${ }^{3}$ Universidad Austral de Chile, RINA - Research Unit on Natural and Anthropogenic Risk,

Valdivia, Chile

${ }^{4}$ Flumen Institute, Universitat Politècnica de Catalunya, Technical University of Catalonia

(UPC - BarcelonaTech)

${ }^{5}$ School of Geography, University of Lincoln, Lincoln, UK

${ }^{6}$ Centro de Investigación para la Gestión Integrada de Desastres Naturales (CIGIDEN),

Santiago, Chile

This article has been accepted for publication and undergone full peer review but has not been
through the copyediting, typesetting, pagination and proofreading process which may lead to
differences between this version and the Version of Record. Please cite this article as doi:
$10.1002 /$ esp. 4603

This article is protected by copyright. All rights reserved. 
${ }^{7}$ Laboratory of Forest Ecosystem Management, Department of Forest Science, Graduate

School of Agriculture, Hokkaido University, Kita 9 Nishi 9, Kita-ku, Sapporo, Hokkaido 060-8589, Japan

${ }^{8}$ Department of Ecosystems and Environment, Pontificia Universidad Católica de Chile, Santiago, Chile

${ }^{9}$ Swiss Federal Research Institute WSL, Zürcherstrasse 111, 8903 Birmensdorf, Switzerland ${ }^{10}$ Department of Earth Sciences, University of Geneva, Geneva, Switzerland

${ }^{11}$ Department F.-A. Forel for Aquatic and Environmental Sciences, University of Geneva, Geneva, Switzerland

${ }^{12}$ Department of Geosciences, Colorado State University, Fort Collins, CO 80523, USA

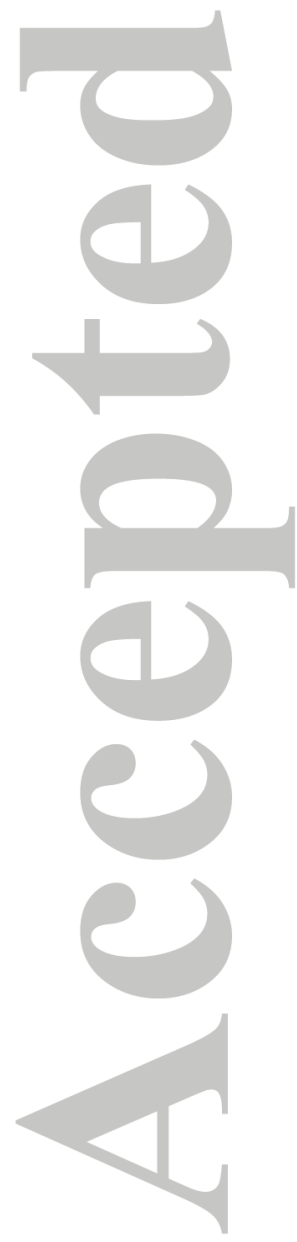




\section{Abstract:}

Inorganic sediment is not the only solid-fraction component of river flows; flows may also carry significant amounts of large organic material (i.e., large wood), but the characteristics of these wood-laden flows (WLF) are not well understood yet. With the aim to shed light on these relatively unexamined phenomena, we collected home videos showing natural flows with wood as the main solid component. Analyses of these videos as well as the watersheds and streams where the videos were recorded allowed us to define for the first time WLF, describe the main characteristics of these flows and broaden the definition of wood transport regimes (adding a new regime called here hypercongested wood transport). According to our results, WLF may occur repeatedly, in a large range of catchment sizes, generally in steep, highly confined single thread channels in mountain areas. WLF are typically highly unsteady and the log motion is non-uniform, as described for other inorganic sediment-laden flows (e.g., debris flows). The conceptual integration of wood into our understanding of flow phenomena is illustrated by a novel classification defining the transition from clear water to hypercongested, wood and sediment-laden flows, according to the composition of the mixture (sediment, wood, and water). We define the relevant metrics for the quantification and modelling of WLF, including an exhaustive discussion of different modelling approaches (i.e., Voellmy, Bingham and Manning) and provide a first attempt to simulate WLF. We draw attention to WLF phenomena to encourage further field, theoretical, and experimental investigations that may contribute to a better understanding of flows river basins, leading to more accurate predictions, and better hazard mitigation and management strategies.

Keywords: woody debris, flood, debris flow, instream large wood, , volunteered geographic information, numerical modelling. 


\section{Introduction}

Criteria used to distinguish between flows vary greatly (Pierson and Costa, 1987;

Coussot and Meunier, 1996; Cruden and Varnes, 1996; Hungr et al., 2001), but are commonly established according to their solid volume concentration, grain size distributions, flow front speeds, shear strengths and rates and depositional forms (Carter, 1975; Iverson, 1997). Importantly, these classifications usually consider inorganic sediment as the only component of the solid fraction, neglecting the role of organic material. Large amounts of organic material, including entire trees, logs, branches, root wads, and smaller wood can be naturally carried by floods and debris flows (Lancaster et al., 2003; Ruiz-Villanueva et al., 2016; Comiti et al., 2016; Mazzorana et al., 2017; Steeb et al., 2017). The common neglect of this component in describing flows might reflect at least two circumstances. First, after centuries of forest, river, and torrent management, organic load in rivers has been reduced significantly worldwide despite its key ecological functions (Lisle, 2002; Wohl, 2014). Secondly, this neglect might reflect the intrinsic difficulty of rigorously developing the physics involved in such a flow where wood pieces of varying densities, shapes, and orientations are simultaneously colliding, sliding, rolling, saltating, and interacting with each other, with the fluid and with the channel boundaries (Grant, 2018, pers. comm). Analogies exist between wood and inorganic sediment (Gurnell, 2007), but the physics of wood transport may differ significantly from that of sediment transport because of differences in piece shape, density, and size of the mobile constituents (Gilbert, 1914; Braudrick et al., 1997). The lack of direct observations of events in which organic material plays a significant role makes it difficult to characterize such flows, analogous to the study of sediment transport in the first half of last century (Braudrick and Grant, 2000). Since then, monitoring techniques and physical and numerical models have contributed greatly to our present knowledge of sediment transport (Kondolf et al., 2005; Gyr and Hoyer, 2006; Tsutsumi and Laronne, 2017; Rickenmann, 2016 and 2017), but wood 
transport has received much less attention. Pioneering observations described wood as an important component in debris flow deposits (Swanson and Lienkaemper, 1978; Nakagawa et al., 1994; May, 2002; Lancaster et al., 2003; Shrestha et al., 2012), but flows in which wood is the main solid fraction (both in terms of mass and volume) have been rarely described. We follow here the nomenclature of particle-laden flows (Delannay et al., 2017) to define woodladen flows (WLF) as a class of two- or three-phase flow. The main phase consists of wood pieces of different sizes, that might be transported in water (second phase), in which inorganic sediment (both suspended and bedload) can be present (third phase). Examples have been recently reported for mountain streams in Chile and Switzerland (Ravazzolo et al., 2017; RuizVillanueva et al., 2017 and 2018).

Some decades ago, video tapes proved a powerful source to gain qualitative insights into the characteristics of flows, particularly debris flows (Costa and Williams, 1984). However, WLF may not be as common as other sediment-laden flows (e.g. debris flows), resulting in a lack of observations. The recent increase in the availability of recording devices such as mobile phones and the publication of home movies on the internet opens up new ways of both gathering extensive data and accessing environmentally relevant information (Paul et al., 2017; Lewis and Park, 2018), and provides the opportunity to encounter valuable information about rare phenomena which can contribute to reducing the associated lack of knowledge (Borga et al., 2008; Buytaert et al., 2014; Le Boursicaud et al., 2016).

This work aims at describing and characterizing WLFs that, although known to exist, are in general underappreciated and overlooked phenomena, resulting in many knowledge gaps. Here, we aim to define and characterize wood transport regimes, key WLF variables, such as velocity or relationship with water discharge, and the catchments and streams where WLF may form and propagate. To do so, we extract and interpret qualitative and quantitative information from home movies that allows us to propose novel conceptual models to better 
integrate wood into our understanding of flow phenomenology. In addition, we discuss different approaches to quantify and model WLF, and attempt for the first time to simulate numerically WLF using three single-phase models, namely Voellmy, Bingham and Manning flow models.

\section{Material and Methods}

By carrying out different online searches (mostly in Google and YouTube) based on a set of technical keywords related to floods, flash floods and wood load (e.g., woody debris, flood and wood, organic debris, etc.) in English, German, Spanish, French, Italian and Japanese, we found 45 home videos showing individual floods transporting a notable amount of wood. From this set of videos, 28 movies recorded in 24 streams in 7 countries were selected for further analyses, as some videos showed the same event, or could not be located, or the quality of the image was not sufficient for our purposes (Fig. 1 and Table S1 in supplementary information).

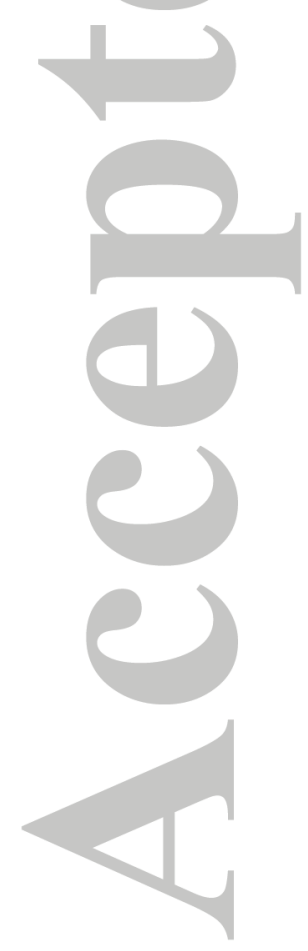




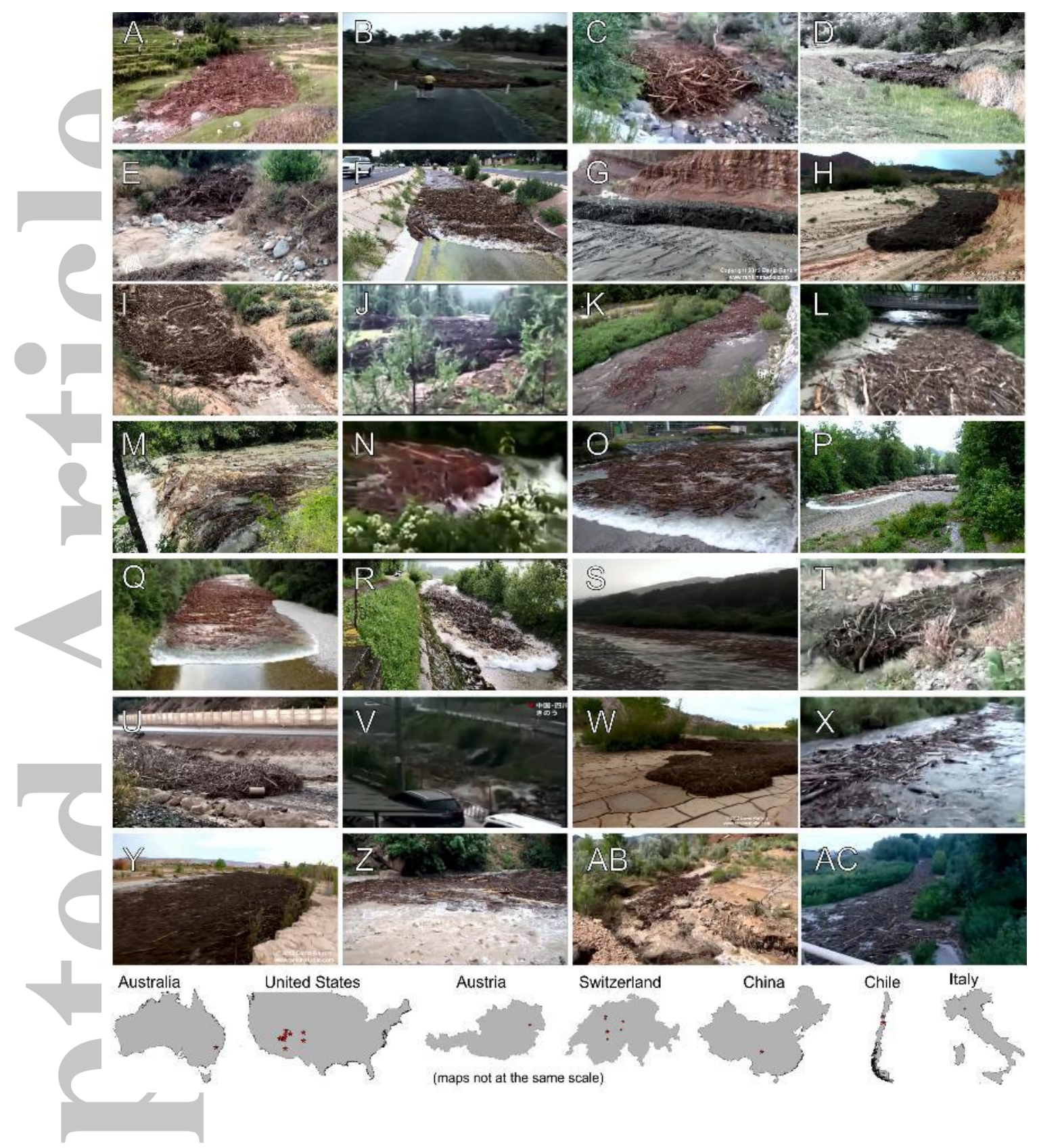

Figure 1: Images of wood-laden flows extracted from the 28 home movies analysed in this work. The location of some of the videos is shown in the maps. Details about the videos are provided in Table S1.

The owners or publishers of the videos were contacted when contact details were found, and videos were downloaded from the internet using Keepvid.com, when not directly provided by the publishers. In some cases, license was required and acquired accordingly. When contacting the video publishers, we also asked for additional information, such as the exact coordinates of the footage site, or details about the event (exact date, any details about the precipitation, discharge, etc.). The quality of the downloaded videos varied significantly, 
ranging between $326 \times 180$ and $1920 \times 1080$ pixels resolution, and from 24 to 30 frames per second sampling rate. Details of the sensors used to record the movies were not available.

After contacting the video owners, videos were processed. Many of the videos include handheld cameras, zoom variations and other movements (e.g., movements from upstream to downstream), or were edited before being published online. Free Video to JPG Converter, Pelscope and Tracker software were used to extract 1 frame per second from each video for further analyses (Fig. S1 in supplementary material). In some cases, additional improvements were achieved such as frame stabilization or orthorectification. For these processes, Gimp, Digimizer, CorelDRAW and Fudaa-LSPIV were used (Le Boursicaud et al., 2016).

Ground information was also collected, including watershed and stream characteristics

(Table 1 and Table S2), and when possible, ground control points were acquired in the field using a differential GPS.

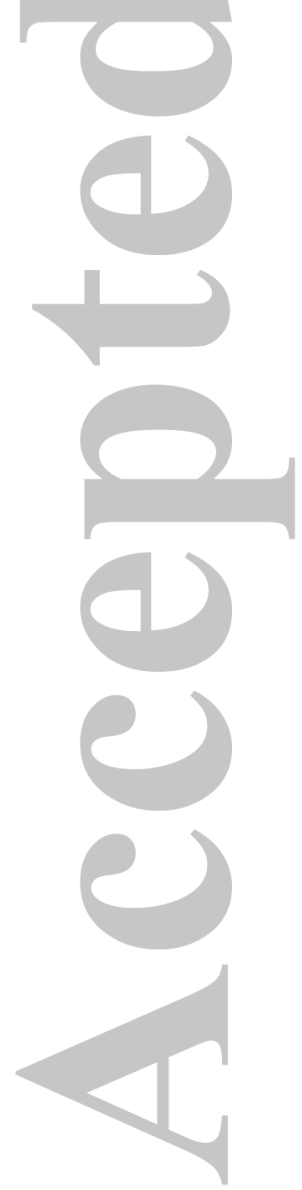


Table 1: Watershed and stream metrics extracted from the videos.

\begin{tabular}{|c|c|c|}
\hline Metrics and variables & Units or classes & Description \\
\hline Drainage area & $\mathrm{km}^{2}$ & $\begin{array}{l}\text { at the point where video was } \\
\text { recorded }\end{array}$ \\
\hline ted area & $\mathrm{km}^{2}$ & $\begin{array}{l}\text { at the point where video was } \\
\text { recorded }\end{array}$ \\
\hline ea & $\%$ & \\
\hline e channel, & $\mathrm{m}$ & $\begin{array}{l}\text { mean value for the reach visible } \\
\text { in the video }\end{array}$ \\
\hline Bankfull height & $\mathrm{m}$ & $\begin{array}{l}\text { mean value for the reach visible } \\
\text { in the video }\end{array}$ \\
\hline Channel gradient & $\mathrm{m} / \mathrm{m}$ & $\begin{array}{l}\text { value for the reach visible in the } \\
\text { video }\end{array}$ \\
\hline Typ & $\begin{array}{l}\text { S: single-thread; W: } \\
\text { wandering; M: meandering; B: } \\
\text { braided; A: anastomosed } \\
\text { (anabranch) }\end{array}$ & \\
\hline River morphology & $\begin{array}{l}\text { C: cascade; SP: step-pool; PR: } \\
\text { pool-riffle; PB: plane bed }\end{array}$ & \\
\hline ents & $\begin{array}{l}\text { 1: one bank; 2: two banks; } 0 \text { : } \\
\text { natural }\end{array}$ & \\
\hline Confinement & H: high; M: medium; L: low & $\begin{array}{l}\text { the degree to which the lateral } \\
\text { extent of the valley floor and } \\
\text { the floodplain along a river is } \\
\text { limited (e.g., by hillslopes, } \\
\text { topographical features, etc.). }\end{array}$ \\
\hline Bed grain size & $\begin{array}{l}\text { B: boulders; C: cobble; G: } \\
\text { gravel; S: sand; F: finer than } \\
\text { sand }\end{array}$ & Visually estimated \\
\hline Peak discharge & $\mathrm{m}^{3 \cdot} \mathrm{s}^{-1}$ & \\
\hline Return period & years & \\
\hline $\begin{array}{l}\text { Suspended load } \\
\text { (turbidity) }\end{array}$ & H: high; M: medium; L: low & As observed in the video \\
\hline Bed load & Y: Yes; N: No & When visible \\
\hline
\end{tabular}




\begin{tabular}{|c|c|c|}
\hline Total precipitation & $\mathrm{mm}$ & \\
\hline Duration precipitation & $\mathrm{h}$ & \\
\hline Rainfall intensity & $\mathrm{mm} / \mathrm{h}$ & \\
\hline $\begin{array}{l}\text { Processes in the } \\
\text { catchment }\end{array}$ & $\begin{array}{l}\text { L: landslide; DF: debris flow; } \\
\text { B: bank erosion; O: other }\end{array}$ & $\begin{array}{l}\text { As documented or observed in } \\
\text { the aerial imagery }\end{array}$ \\
\hline Origin of wood & $\begin{array}{l}\text { F: freshly recruited (presence } \\
\text { of roots with soil and branches } \\
\text { with leaves); D: previously } \\
\text { deposited (decayed, may also } \\
\text { include branches and/or root } \\
\text { wads) }\end{array}$ & \\
\hline Initial water level & $\begin{array}{l}<0.1 \mathrm{~m} ; 0.1-0.5 \mathrm{~m} ; 0.5-1 \mathrm{~m} ;> \\
1 \mathrm{~m}\end{array}$ & \\
\hline Overbank flow & Y: Yes; N: No & \\
\hline Total duration of video & $\min$ & \\
\hline $\begin{array}{l}\text { Number of frames } \\
\text { analyzed }\end{array}$ & $\mathrm{N}^{\mathrm{o}}$ & \\
\hline $\begin{array}{l}\text { Time in video for each } \\
\text { phase }\end{array}$ & $\mathrm{sec}$ & \\
\hline Duration of each phase & $\sec$ & \\
\hline $\begin{array}{l}\text { Flow velocity during } \\
\text { each phase }\end{array}$ & $\mathrm{m} / \mathrm{sec}$ & \\
\hline $\begin{array}{l}\text { Movement of logs } \\
\text { during phase }\end{array}$ & $\begin{array}{l}\mathrm{R} \text { : rolling, } \mathrm{S} \text { : sliding, } \mathrm{F} \text { : } \\
\text { floating }\end{array}$ & \\
\hline $\begin{array}{l}\text { Cross section (width) } \\
\text { occupied by wood } \\
\text { during each phase }\end{array}$ & $\mathrm{m}$ & \\
\hline $\begin{array}{l}\text { Cross section occupied } \\
\text { by wood during each } \\
\text { phase }\end{array}$ & $\%$ & \\
\hline Size of logs: length $\mathrm{L}_{50}$ & $\mathrm{~m}$ & $\begin{array}{l}\text { Mean (measuring the } 5 \text { largest } \\
\operatorname{logs} \text { ) }\end{array}$ \\
\hline $\begin{array}{l}\text { Size of logs: diameter } \\
\mathrm{D}_{50}\end{array}$ & $\mathrm{~m}$ & $\begin{array}{l}\text { Mean (measuring the } 5 \text { largest } \\
\operatorname{logs})\end{array}$ \\
\hline $\begin{array}{l}\text { Shape of logs during } \\
\text { each phase }\end{array}$ & L: logs; B: branches; R: roots & \\
\hline
\end{tabular}


When no field survey was possible, the exact location of the video was found (e.g., provided by the publishers) and available high-resolution satellite images from Google Earth were used to obtain control points. The control points were used to extract metrics, such as flow depth, flow velocity (estimated based on time and distance travelled by the flow mass or single pieces), size of logs (5 largest logs were measured using ImageJ; Fig. S1), stream gradient, width and height of the bankfull channel. The general type and morphology of streams were classified as: (i) single-thread, wandering, meandering, braided or anastomosed; (ii) cascade, step-pool, pool-riffle and plane bed. If embankments (i.e. artificial bank) were observed, we noted this characteristic, as well as the degree of lateral confinement. Other characteristics were extracted visually, such as instream bed grain size, classified in five groups: boulder, cobble, gravel, sand and finer than sand; the initial water level, also classified as: $<0.1 \mathrm{~m} ; 0.1-0.5 \mathrm{~m} ; 0.5-1 \mathrm{~m} ;>1 \mathrm{~m}$ and the suspended load based on the turbidity, classified as low (e.g., Fig. $1 \mathrm{O}$ and Q), medium (e.g., Fig. 1L and Z) and high (e.g., Fig. 1A and Y). Drainage areas were obtained from Stream Stats (USGS; Wilkowske et al., 2011), Hydrosheds (USGS) flow accumulation raster files, and the geodata set from Swisstopo. Shooting sites were classified according to the climatic zones defined by Peel et al. (2007). In some cases, detailed information about forest cover was available. If such information was not available, relevant metrics were visually estimated based on high resolution satellite images. Information on precipitation and discharge of the events was rarely available.

Table S2 in supplementary material show the metrics extracted for each analysed video.

\section{Results}

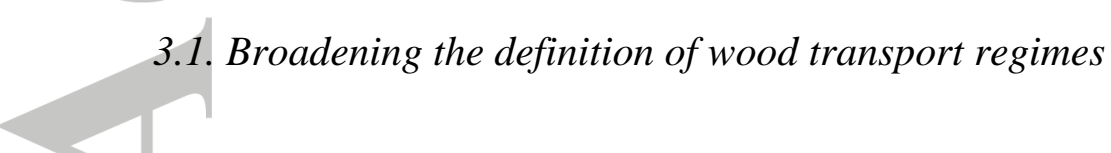

Based on the analysis of the videos and the extracted data described above, we define four different flow regimes or stages for WLF (Fig. 2 and video provided as supplementary 
material), thus adding an additional one to the traditional three regimes proposed by Braudrick et al., (1997). As videos mostly show WLF developed during floods (and not during debris flows), flow is defined here as a two-phase model according to the proportions of wood and water, but a three-phase model may apply for WLF with higher content of inorganic material. The proportion of water and wood can be described by the ratio of wood (wood volume per unit time) and water discharge, but, as we could not obtain wood fluxes or discharges, we use the wood flow depth $(z)$ and the water depth $(h)$ to distinguish between hypercongested, congested, and uncongested regimes. Hypercongested regime: a downstream moving log mass (or volume) with several layers of wood (wood flow depth, $z$, equal to several times the wood piece diameter, $d_{w}$; Figure 2 ) occupying the entire wetted cross-section, usually spanning the whole channel width. Wood moves with piece-to-piece contacts, and logs may rotate or pivot in the mass (or volume). Most of the logs are oriented perpendicular and oblique to the flow direction. Two hypercongested flow front types (i.e., dry and wetted) were observed in the videos: (i) Dry hypercongested wood front: $\operatorname{logs}$ are mainly rolling or sliding on the riverbed and not floating, with a very low or even zero water depth $\left(h \ll<\right.$ and $\mathrm{z}=k \cdot d_{w}$, where $k>3$ (based on our observations, but more data are needed to confirm this value)); (ii) Wetted hypercongested wood front: the wood front is preceded by a water surge (antecedent water level or precursory surge, and the wood mass is formed by mostly floating logs (i.e., $h>=z$ ) that may also pivot and rotate in several layers of wood $\left(\mathrm{z}=k \cdot d_{w}\right.$ where $\left.k>3\right)$.

During the hypercongested regime, the mass of wood appeared not to be saturated with water; frictional forces, $F_{f}$, dominate (both friction between wood pieces and friction between wood and the channel bed), and the flow is likely moving similarly to a slurry-flow, rock avalanche or debris flow boulder front. Sliding may occur when a large mass of moving logs encounters stationary logs and pushes them downstream. 
Thirty-seven percent of the analysed videos showed sliding and rolling WLF dry fronts. Channel gradient, river type and channel morphology (Fig.2) are relevant variables for the dry front formation and propagation. The dry fronts were observed in the steepest (mostly mountain rivers with a median elevation > $1000 \mathrm{~m}$ a.s.l.; Fig. S2E) and generally in narrower (although differences were not significant compared to streams where not dry front was observed; Fig. S2C) channels. In $82 \%$ of the cases when a dry hypercongested front was observed, the initial estimated water level was lower than $10 \mathrm{~cm}$ (Fig. 3H). In some cases, the dry front was only developed as small dry lobes over bars that were initially dry (e.g., the Zulg River in 2012). In those cases where we could extract front depth values at different front flow sections, we observed values ranging between 0.7 and $3.7 \mathrm{~m}$, with flow longitudinal slopes ranging between 0.09 and $0.7 \mathrm{~m} \cdot \mathrm{m}^{-1}$, much higher than the channel longitudinal slope (ranging for those cases between 0.003 and $\left.0.07 \mathrm{~m} \cdot \mathrm{m}^{-1}\right)$.

Behind this high-friction one single-phase (wood) flow front come lower-friction phases, characterized by a liquefied flow that contains a lower percentage of woody material. Congested regime: this is the well-known congested regime where floating logs $\left(h>z ; z=k \cdot d_{w}\right.$ where $k<3$; Fig. 2) touch each other while moving as a single floating mass or carpet occupying a large part of the cross-sectional area (Braudrick et al., 1997). The orientation of the logs varies; many logs are oriented perpendicular to the flow direction, while others are oriented parallel, especially at the channel margins. During this regime, water content is much higher than during the hypercongested regime, likely increasing the buoyancy of wood. Buoyancy force, $F_{b}$, is an important aspect of this two-phase flow regime, because it enhances wood flow mobility by reducing the frictional resistance.

As water content increases and wood volume decreases, the transition between congested and fully uncongested flow can be gradual through a semi-congested regime (Fig. 2). Uncongested regime: in this phase $\operatorname{logs}$ float $\left(h \gg>\right.$ and $z=d_{w}$ Fig.2), do not interact with 
each other, and occupy a very small part of the cross-sectional area (Braudrick et al., 1997). In this regime, logs are usually transported aligned with the flow.

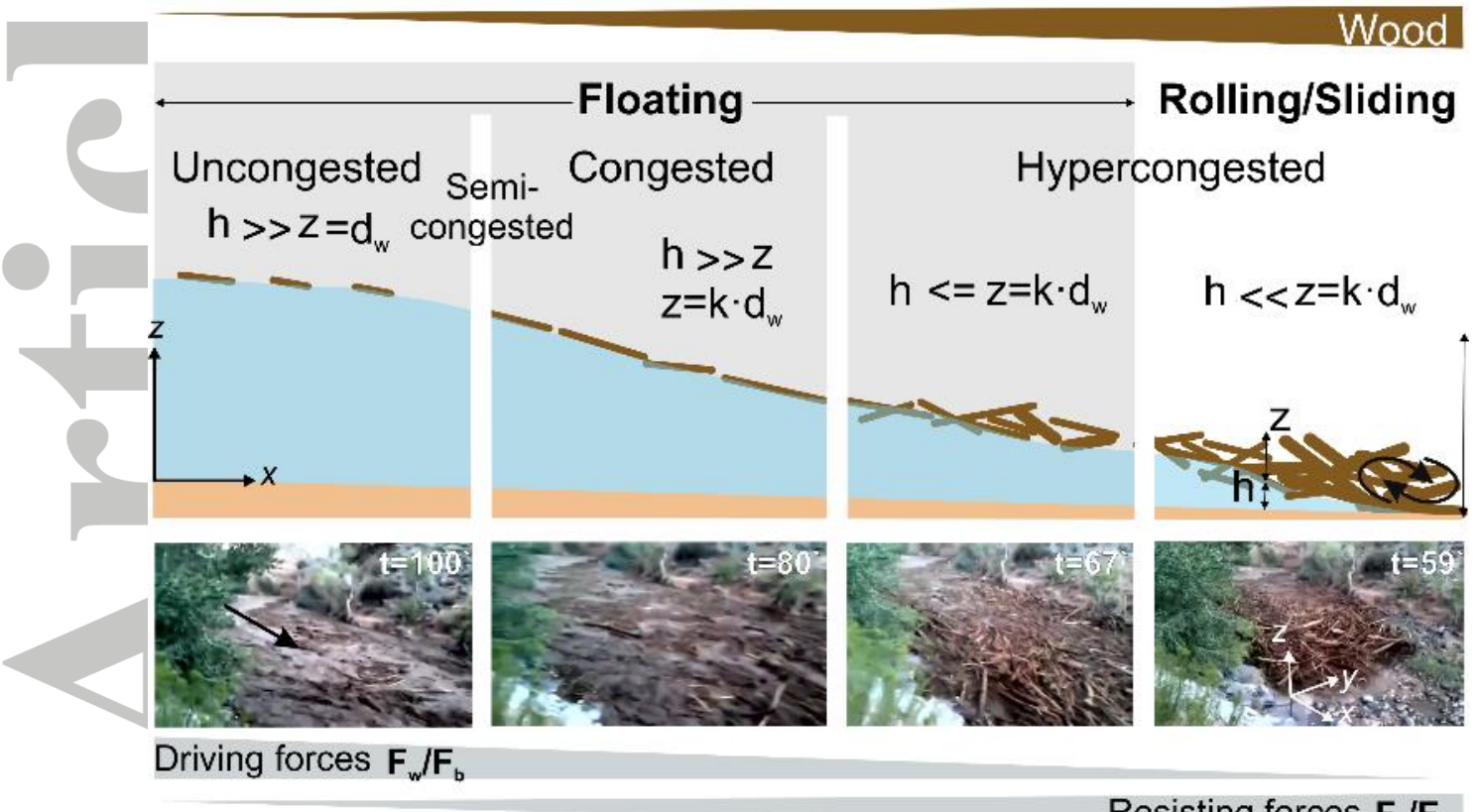

Figure 2: Wood transport regimes. Images (Video North Creek) show the same river section at different times $(t) . h$ : water depth and $z$ : wood flow depth; $d_{w}$ : wood piece diameter; $k$ : coefficient $>1 ; F_{b}$ : buoyancy force; $F_{d}$ : drag force; $F_{f}$ : friction force; $F_{w}$ : weight;

These flows are inherently unsteady. Within a single event, different regimes with distinctive flow characters may develop throughout the duration of the event and along the propagation path (Fig. 2). However, not all WLF in the videos showed the four regimes. Additional data would be needed to better explain why, although here we discuss some potential controlling factors to form and propagate the hypercongested front based on our observations (section 3.2 and discussion)

\subsection{Observed Wood-laden flow characteristics}

Flow velocity was highly variable depending on the event. High values of flow velocity were estimated for the event in the Marquesa stream in Chile (with values between 9 and 17 
$\mathrm{m} \cdot \mathrm{s}^{-1}$ ), while median values were in most cases lower than $5 \mathrm{~m} \cdot \mathrm{s}^{-1}$. For the cases where the three above-mentioned phases (hypercongested, congested and uncongested) were recorded, we observed a velocity gradient in which the hypercongested (both wet and dry fronts) flow phase was slower than the subsequent congested and uncongested regimes (Fig. 3).

As observed in the videos, the majority of woody material is transported at the flow front in a very short time (most videos lasted a few minutes). Thus, the peak of the wood flux occurred prior to the peak of the water flow, and the front of the wood flow showed a very low water level. The conceptual relationship between the wood flux and the water discharge is shown in Figure 3.
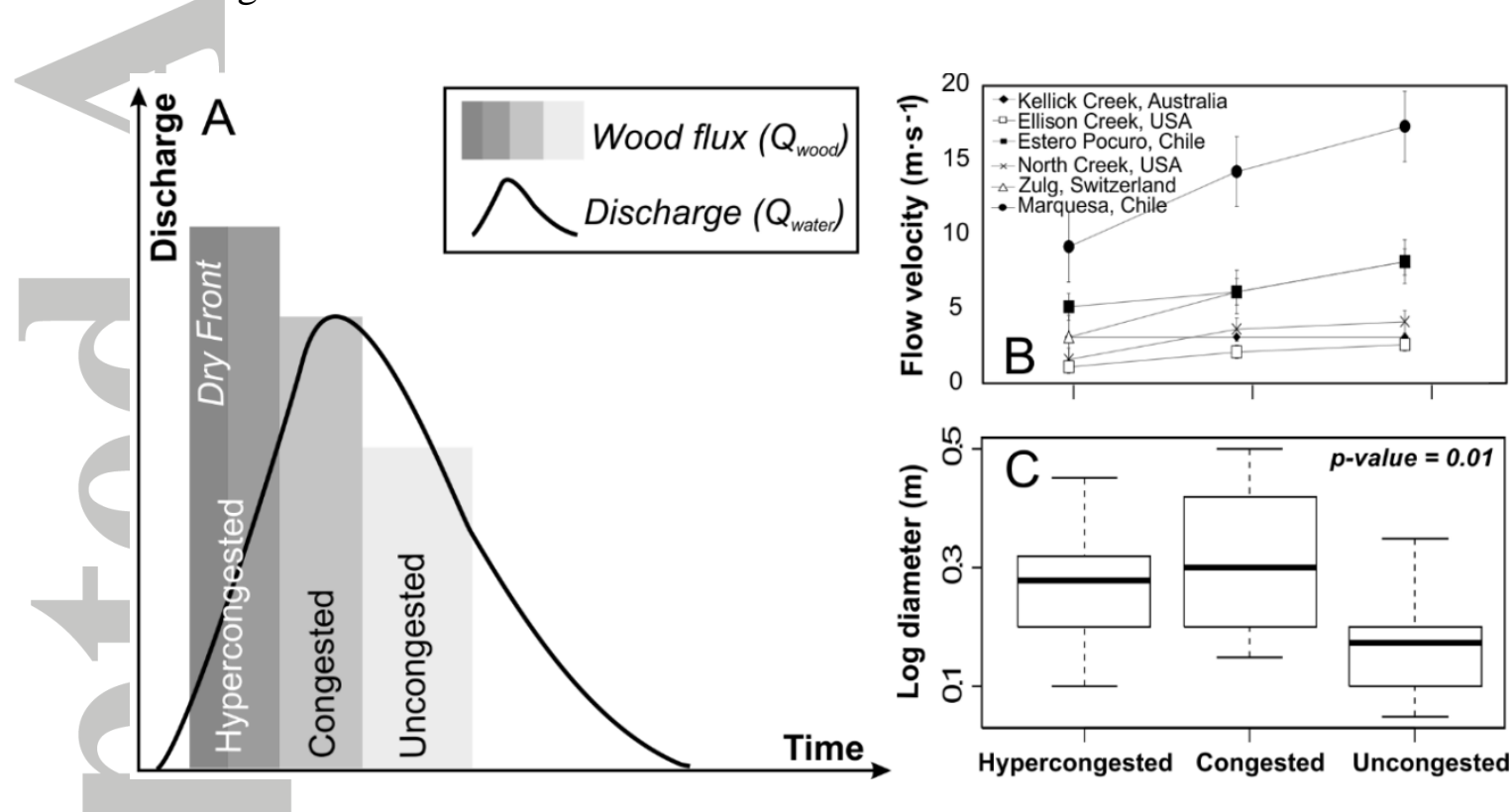

Figure 3: (A) Conceptual model for the relationship between the water discharge $\left(Q_{\text {water }}\right)$ and the wood flux $\left(Q_{\text {wood }}\right) ;(B)$ Wood flow velocity estimates from videos where the three regimes were observed; $(C)$ wood pieces diameter estimated from videos for each WLF regime.

Under hypercongested conditions, the velocity of the front moving near the riverbed can be considered a single phase mostly composed of wood, and the flow velocity may be reduced by friction (both due to current and wood shear), which depends mostly but not entirely on the roughness of the bed. Important factors might be the friction and collision among pieces (i.e., wood-wood or between wood and inorganic sediment particles), which may significantly 
increase flow resistance and energy dissipation, maintaining a slower front. Differences in flow velocity facilitate development of the front, with wood pieces that are conveyed and supplied from upstream reaches (pieces moving faster), as observed in some videos (e.g., Pocuro stream, Chile). Therefore, logs are being recruited into the flow by an exchange between the front and other parts of the flow, and between the front and the enclosing channel.

Generally, larger logs were observed during the hypercongested and congested flow regimes, while significantly smaller logs appeared during the uncongested phase (Fig. 3C).

\subsection{Watersheds and streams where wood-laden flows occurred}

WLF were recorded within different climatic zones: $43 \%$ in Cold and Polar/Tundra zones (ET, Dfb, Dfc, Dsc, and Dwa in Austria, Switzerland, Utah in the USA and Valparaiso in Chile), 35\% in Arid zones (Bsk and Bwk in Utah, New Mexico, Colorado in USA and Elqui in Chile), and 22\% in Temperate zones (Cfa and Csa in Italy, Australia and Arizona, US; Cwb in China), Videos were recorded at different elevations (Fig. S2E; ranging between 48 and $2198 \mathrm{~m}$ a.s.1.), mostly although not entirely in mountain areas (median= $839 \mathrm{~m}$ a.s.1.). A majority of WLF were recorded in small to medium size catchments (Fig. S2A, drainage areas ranged between 28 (Camp Creek) and $3465 \mathrm{~km}^{2}$ (Paria River), median $=182 \mathrm{~km}^{2}$ ), and thus in small to medium channels (Fig. S2C); with bankfull widths ranging between 4.5 (Camp Creek) and $50 \mathrm{~m}$ (Emme River) (median=17 $\mathrm{m}$ ) and bankfull depths between 1.5 and $4 \mathrm{~m}$ (Fig. S2D). Channels were relatively steep (Fig. S2B), with a longitudinal slope between 0.0016 (Emme River) and $0.07 \mathrm{~m} \cdot \mathrm{m}^{-1}$ (Pocuro stream) $\left(\right.$ median $\left.=0.012 \mathrm{~m} \cdot \mathrm{m}^{-1}\right)$. The forested area ranged between 10 (Sulphur Creek) and $71 \%$ (Ellison Creek) (Fig. S2F; median $=37 \%)$.

Most of the streams (66\%) were straight single-thread channels with pool-riffle and plain-bed morphologies (82\%; Fig. 4A). The streams were in general highly or moderately 
laterally confined (79\%; Fig. 4C). Artificial embankments were frequently present along one or both banks (48 \%; Fig. 4D), although a majority of streams showed natural banks without embankments $(52 \%)$. Channels without artificial embankments were mostly highly and moderately confined $(80 \%)$.

The characteristic grain size in most cases (82\%) was gravel, cobbles and boulders, with only $18 \%$ characterised by finer material (e.g., sand) (Fig. 4E). In $72 \%$ of the events, bedload transport was not visible (Fig. 4G), but the movies were not meant to record bedload transport explicitly. The high turbidity observed in the flows indicates a medium to high concentration of suspended load (77\%; Fig. 4F). In most of the events (73\%) no overbank flow was recorded, and the initial water level was relatively low (Fig. $4 \mathrm{H}$ ), with $89 \%$ of cases lower than $0.5 \mathrm{~m}$. Where overbank flow occurred, it was due to the presence of an obstacle such as a road or a culvert.

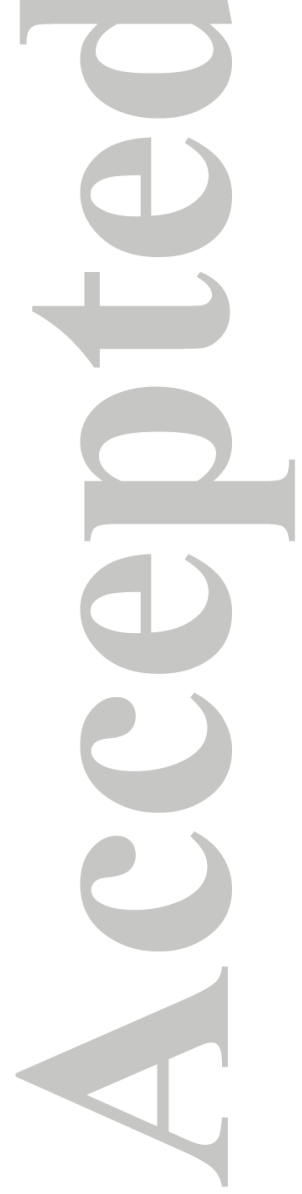



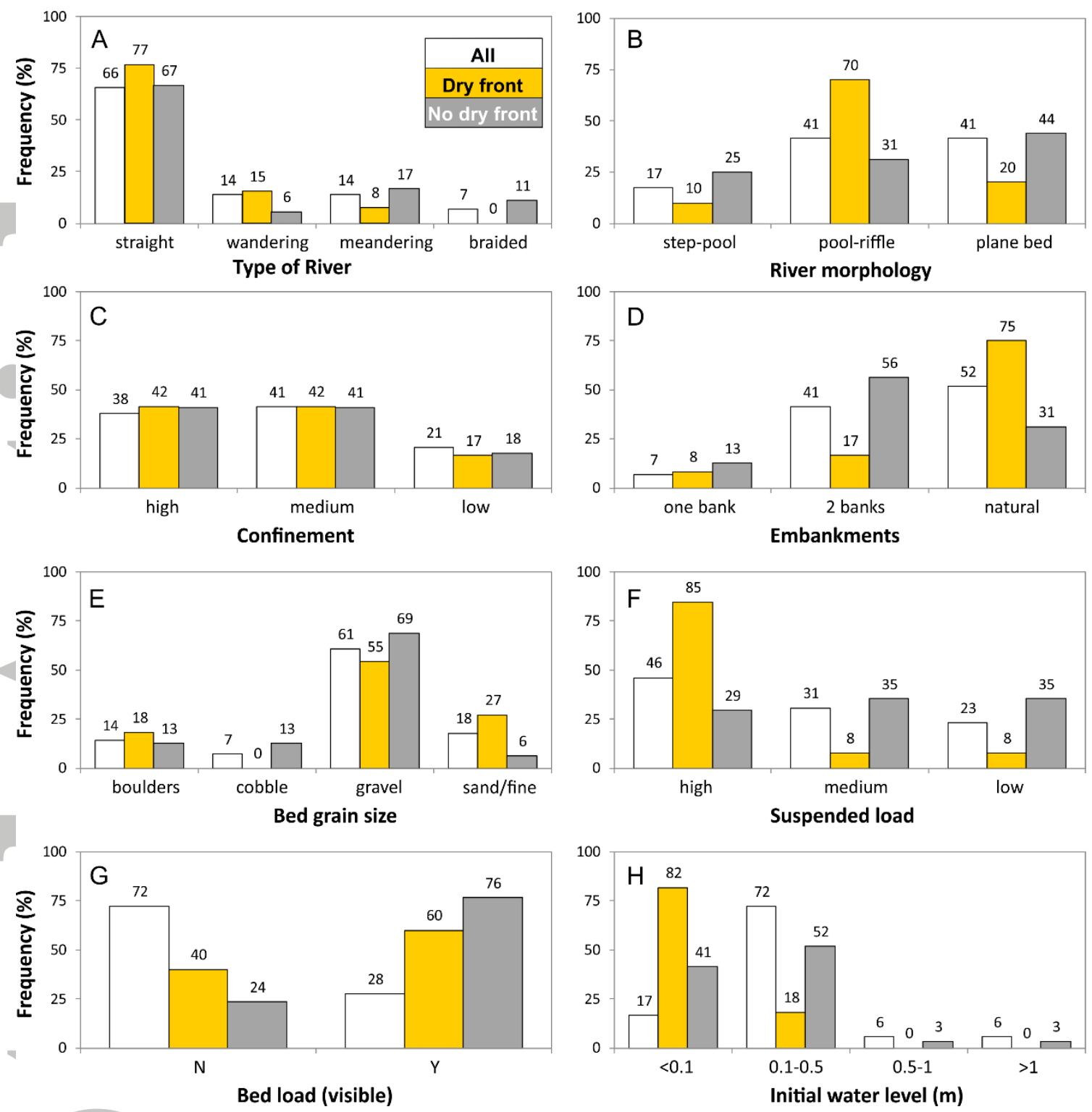

Figure 4: Frequency (\%) of events as classified by: $(A)$ type of river; $(B)$ confinement; $(C)$ river morphology; $(D)$ bed grain size; $(E)$ artificial embankments; $(F)$ suspended load; $(G)$ bed load; $(H)$ initial water level $(m)$ for all flows, flows showing dry front and flows not showing dry front. Values indicate the percentages.

Although repeated WLF might be less frequent, videos recorded at the Zulg River in Switzerland, with 4 WLF events recorded in the last 6 years, show that WLF can occur repeatedly within the same channel. These WLFs occurred during very different hydrological conditions (Fig. 5, Table S1). Events were recorded in 2012, 2013, 2015 and 2016, with recorded discharges equal to $222,83,234$ and $44 \mathrm{~m}^{3} \cdot \mathrm{s}^{-1}$, respectively (Fig. 5). 

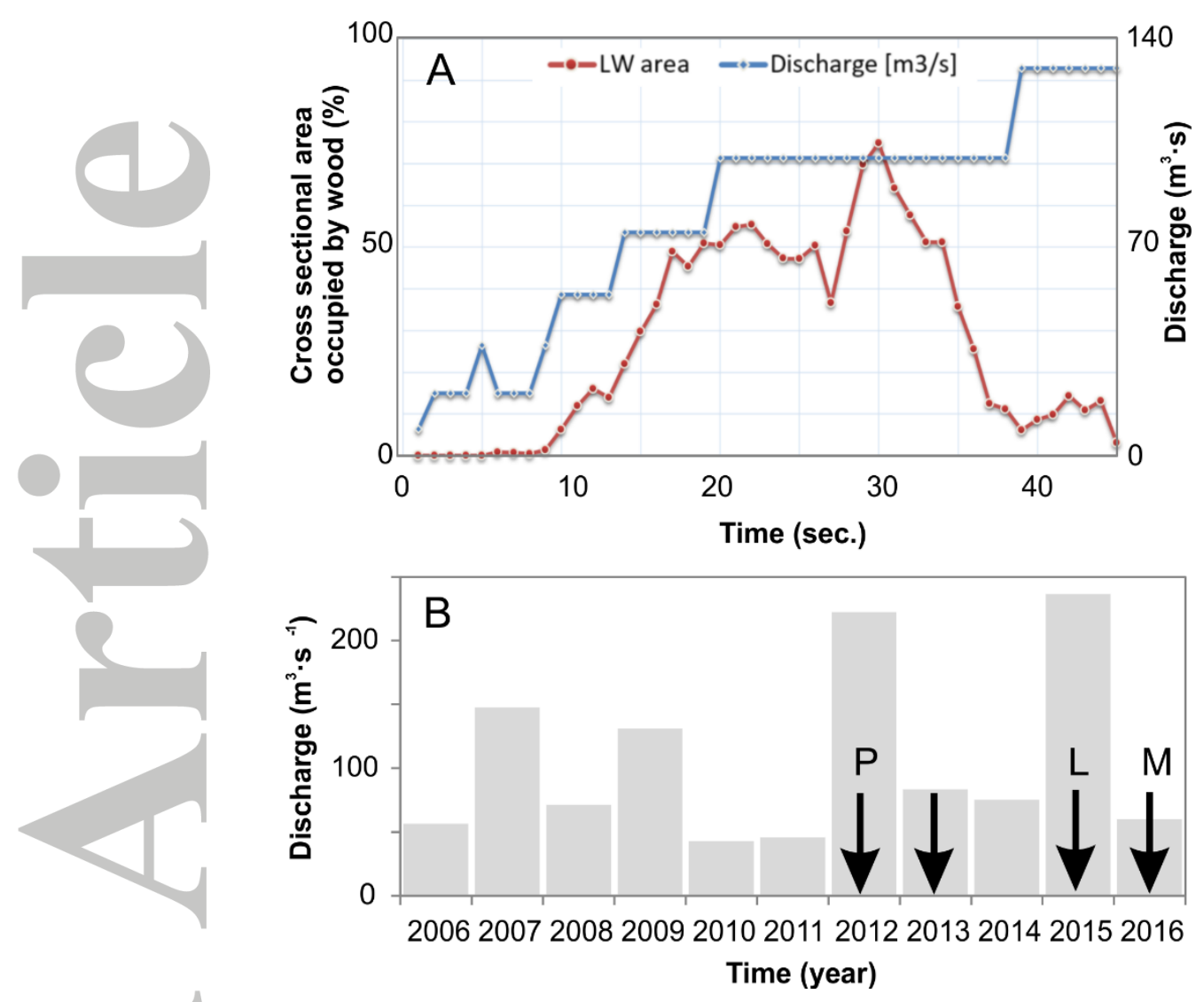

Figure 5: A: Flood hydrograph and wood flux (estimated as a cross sectional area occupied by wood as observed in the videos) for the event recorded in 2015 in the Zulg River (Switzerland); B: Annual maximum discharge recorded in the Zulg River (Switzerland) between 2006 and 2016. Black arrows show years with recorded wood-laden flows, and letters show the videos ID as shown in Fig. 1 and Table S1.

The event in 2012 had the largest amount of wood (around $600 \mathrm{~m}^{3}$ ); according to the videos, 2012 had approximately twice the volume transported during the event in 2015, despite the higher discharge recorded during the latter. This case shows the importance of wood availability and supply to produce WLF (see discussion).

\section{Discussion}

In this study we described for the first time the main characteristics of watersheds and streams where wood-laden flows occurred, and we quantified and conceptualized the most relevant variables of the flows. Home movies have proved to be a relevant source of 
information. However, the videos used in this study were recorded by witnesses, rather than for scientific purposes. Witnesses did not use checks, protocols, and quality-assurance techniques that are employed in field science, which limits the use and data that can be extracted (Robson, 2012; Le Coz et al., 2016; Lewis and Park, 2018). Still, the videos allowed us to extract quantitative and qualitative data, facilitating a first-order understanding of WLF.

WLF exhibit unsteady, non-uniform motion, as described for debris flows (Iverson, 2013). WLF may start to move downstream when frictional forces can no longer resist driving forces, although other mechanisms can be involved in the initiation and propagation of a WLF (see Section 4.3). As for debris flows (Costa, 1984; Iverson, 2003), the hypercongested wood fronts observed at the heads of the flows are similar to the surge fronts at the heads of moving debris flows, followed by a finer grained flow, the uncongested wood flow. The hypercongested wood flow front is the most distinctive aspect of WLF and how it forms and is maintained is crucial to our understanding of these phenomena. Although the dataset analysed here does not allow us to evaluate downstream changes in WLF within a channel or during a single event, it is possible that self-enhancing feedback effects occur as the WLF front erodes the channel banks or fells standing trees, recruiting additional wood into the flow.

According to our observations, WLF can be formed in different climatic regions, with a majority of flows recorded in cold zones and mountain regions. Steep and confined straight single-thread channels are more prone to form and propagate hypercongested wood flows. Confinement and channel embankment seem to also play an important role in the dynamics of WLF, together with the flashy flood character and the initial water level that are also likely to be important in the formation of WLF. Some of the analysed streams where dry fronts were observed, such as those in the US, might be ephemeral and characterized by an intermittent and flashy flow regime. However, WLF were recorded in perennial streams as well (e.g., Emme and Zulg rivers in Switzerland). We believe that WLF might be more common than expected, 
and the lack of videos in other environments does not mean that WLF cannot occur in rivers very different than those presented in our study.

We observed that most of the wood in a WLF was transported at the flow front during the rising limb of the flood hydrograph, meaning that during the falling limb the wood flow is mainly uncongested, and for similar values of discharges the amount of wood in transport decreases during this phase. This agrees with the existence of a clockwise hysteresis loop, as observed in the Zulg River (Switzerland), the Ain River (France; MacVicar and Piégay, 2012) and modelled in the Czarny Dunajec River (Poland; Ruiz-Villanueva et al., 2016), similar to the hysteresis loop class II defined for sediment and water flows (Williams, 1989). However, the water-wood hysteresis might be strongly related to wood supply, entrainment and deposition along the flow path, which might differ from inorganic sediment-water hysteresis.

These considerations are consistent with the observation that WLF enter channels with very low water depth and that these flows are very flashy (i.e., short duration, and rapid rise and recession hydrograph; Baker et al., 2004). Otherwise, wood would tend to float and reduce the contact with the bed, decreasing friction forces and facilitating wood motion, enhancing uncongested, rather than congested or hypercongested, wood transport. In terms of particles and flow interactions, several studies reported the existence of a velocity lag between sediment particles and water in sediment-laden flows (Jha, 2017), usually with particles having a lower velocity than water. In debris flows, flow velocity may decrease by up to $50 \%$ with an increase of the solid content (Chen et al., 2017). Velocity distribution is still one of the most complex problems in the dynamic mechanism of flows (Chen et al., 2017). According to our results, WLF are propagated relatively fast. As observed during other mass flows, mostly debris flows, peak speeds may range from 10 to $23 \mathrm{~m} \cdot \mathrm{s}^{-1}$ (Prochaska et al., 2008; Iverson, 2014). Our estimates showed lower mean values, as expected for water flows. In the steepest streams in 
Chile, however, estimated WLF instantaneous velocities ranged between 9 and $17 \mathrm{~m} \cdot \mathrm{s}^{-1}$. More research is needed to thoroughly understand WLF velocity distribution.

Lancaster et al. (2003) presented one of the first studies to demonstrate that wood might constitute a first order control on runout lengths and deposition of debris flows. However, these authors acknowledged the lack of observations of actual flows in motion, which is necessary to understand the effect of wood on the motion of debris flows. Most data used to describe, quantify and model debris flows and bed load came from field-scale experiments and field observations for which videos were also used (Costa and Williams, 1984; Logan and Iverson, 2007; Badoux et al., 2009; Iverson, 2013). We encourage the same effort to better understand WLF, promoting monitoring, flume and field experiments and modelling. Field experiments, proper monitoring systems, and ad hoc gauges would reduce the related uncertainties and provide more accurate values than those reported here.

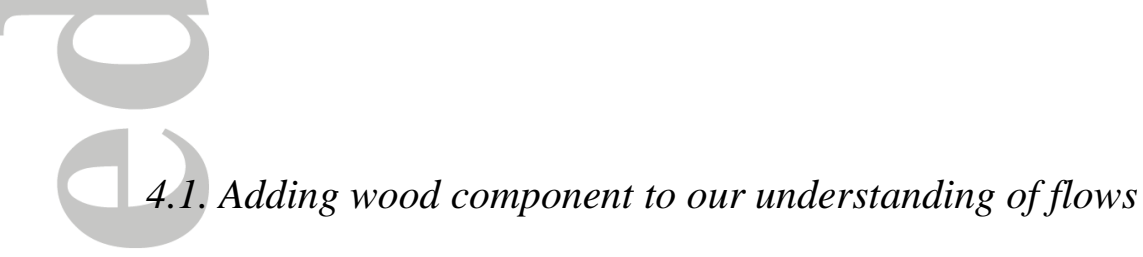

Flow behaviour is, among other properties, a function of the relative proportions of its components (Pierson et al., 1987; Hungr et al., 2001). Therefore, the presence of wood should receive more attention in our understanding of flows, and be better represented in flow classifications, as one may expect different flow behaviour when wood is an additional solid component in the flow (see section 4.2). For that purpose, we propose a ternary diagram to classify flows according to the content of sediment, water and wood (Fig. 6).

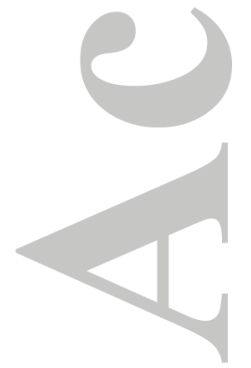



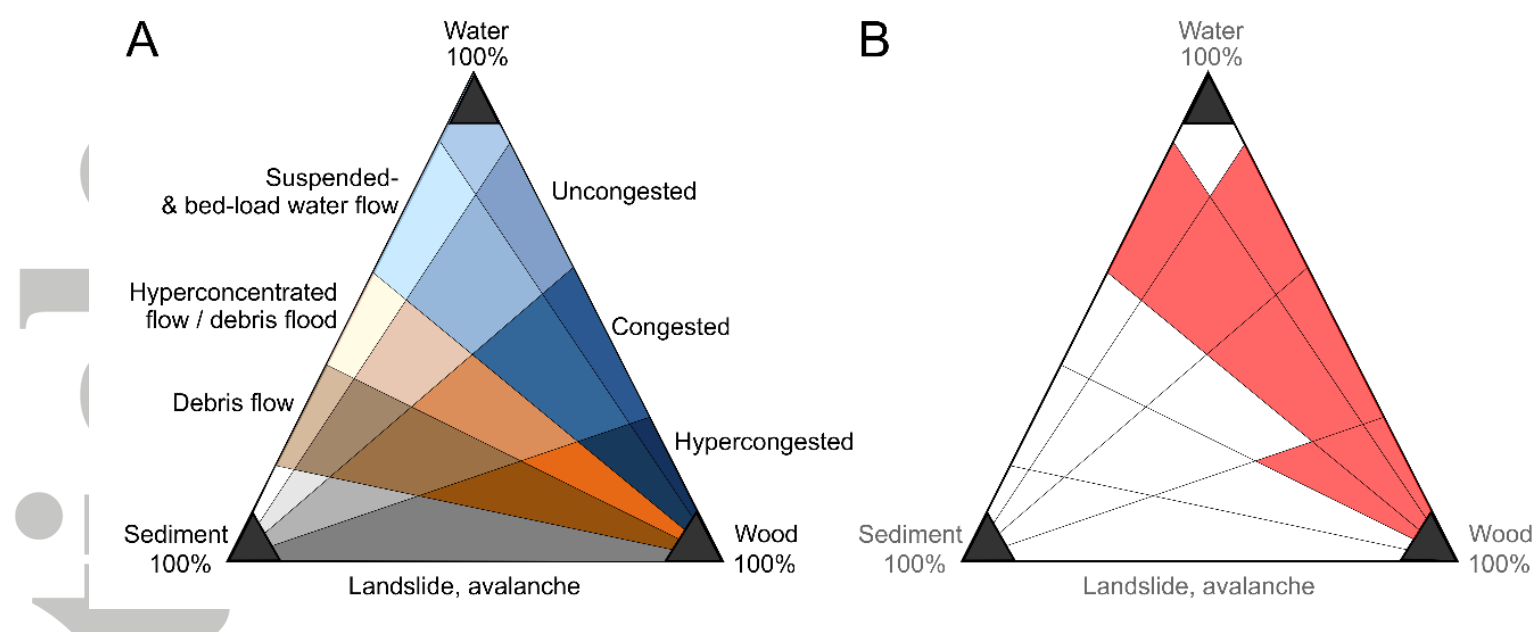

Figure 6: (A) Ternary diagram of sediment-water-wood; (B) Wood-laden flows identified in the videos analysed in this work are coloured in red.

This type of ternary diagram has been commonly used to classify inorganic sedimentladen flows (Phillips and Davies, 1991) based on the proportion of fine and coarse inorganic sediment and water. Here we grouped sediment in one component and added wood as the third component. This classification of the flows could be more detailed based on further parameters, such as log velocities, size of logs, other variables used in the theory of flows (e.g., Iverson, 1997) or different phases of water (e.g., ice). Although the limits between the different flow types are qualitative, they illustrate the relative composition of the mixture of wood-sedimentwater. The exact values of proportions or percentages of sediment, water and wood may require further research.

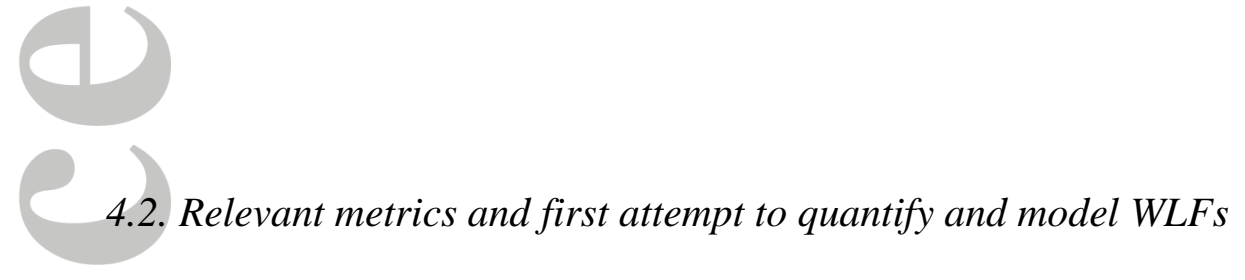

The limitations related to the data extracted from the videos, as explained above, make a detailed description of the WLF mechanics challenging. Therefore, we only attempt here to define the relevant metrics and potential pathways for the detailed quantification and modelling of WLF. As for sediment-laden flows, the kinematic WLF characteristics depend on the topographical and surface friction conditions, the water content, the wood size and sorting and 
on the dynamic interaction between the solid and fluid phases of the mixture (Scheidl et al., 2013).

Recent approaches developed to monitor and measure sediment transport (Roth et al., 2016; Rickenmann, 2017) or flood propagation (Le Boursicaud et al., 2016; Guillén et al., 2017) could provide the data required to better understand WLF dynamics; however, these techniques would need to be tested and adapted to WLF. Flume experiments and modelling may help to understand WLF dynamics. Indeed, Braudrick and Grant (2000) described the physics of individual pieces of wood floating in a water-flow. Following this multi-phase approach, numerical models have been developed using different frameworks, accounting or not for the interphase interactions (e.g., Mazzorana et al., 2011; Ruiz-Villanueva et al., 2014; Persi et al., 2017). To compute wood motion, a Lagrangian or discrete element approach has been combined with a hydraulic model. This approach has been used to simulate individual wood pieces within an uncongested and semicongested wood transport regime, fully coupled to hydrodynamics, in the Iber-Wood model (e.g., Ruiz-Villanueva et al., 2014, 2016, 2017).

Focused on congested wood regime, and assuming a continuous and inflexible carpet (with no porosity and no water in the wood structure) of floating material, Bocchiola et al. (2002) proposed a linear momentum equation which contains the tangential stress acting on the interface between the wood carpet and the water layer. According to this approach, the water flow is subjected to an additional drag force due to the wood carpet and this force can be added to $1 \mathrm{D}$ or $2 \mathrm{D}$ shallow water equation models.

Some approaches have been proposed to include the effect of wood on debris-flow simulations (Lancaster et al., 2003; Shimizu et al., 2006; Shrestha et al., 2009 and 2012). An extension of the Channel-Hillslope Integrated Landscape Development (CHILD) model was presented by Lancaster et al. (2003). The model includes a storm simulation, which drives landslide initiation, fluvial transport, and tree fall. As output, the model computes debris flow 
runout paths and deposited depths of wood and sediment at each point in the channel and valley network. To do so, a reduced version of the Iverson and Denlinger (2001) equation for the conservation of momentum accounting for the relative proportions and densities of sediment, water, and wood is applied.

Hypercongested wood flows have not been described in the literature so far, so we aim here to fill this gap. Although two or three-phase fluid-solid (water, wood and sediment) models may be expected to better reproduce the dynamic behaviour of hypercongested WLF, other approaches can be also used. Single-phase approaches used to characterize Newtonian and non-Newtonian flows (such as those used for debris flows or snow avalanches) assume that the different flow phases are well mixed and the material behaves as a bulk flow (i.e., no distinction between fluid and solid phases), which simplifies the equations and models based on different rheological approaches. Generally, these single-phase approaches assume that the shear stress is the result of the sum of some or all of the following five components: the cohesive yield stress, the Mohr-Coulomb shear stress, the viscous shear stress, the turbulent shear stress and the dispersive shear stress. Therefore, a possible strategy to simulate nonNewtonian shallow flows, such as WLFs, might be to combine the 1D or 2D continuity and momentum equations with such a rheological model (Scheidl et al., 2013). Several rheological models were proposed in the literature (O'Brien et al., 1992; Hungr, 1995; Naef et al., 2006), but probably the Voellmy-Salm model or the Bingham fluid model and the Manning equation are the most extensively used for non-Newtonian and Newtonian flows, respectively.

The Voellmy fluid model is based on a velocity-squared dependent friction term and assumes that the total flow resistance is divided into a dry-Coulomb-like friction mainly due to the solid phase $(\mu)$ and a Chezy-like turbulent friction resistance $(\square)$ (Voellmy, 1955; Hungr, 1995; Bartelt and Gruber, 1999):

$$
s_{f}=\mu+\frac{u^{2}}{\xi \cdot h}
$$


where $S_{f}$ is the friction slope and $u$ the flow velocity. The friction coefficient can also be expressed as $\square=C^{2}$, where $C$ is the Chezy coefficient often used in open channel hydraulics. Available commercial models that use this non-Newtonian rheological approach are DAN3D (McDougall and Hungr, 2005; Hungr and McDougall, 2009), FlatModel (Medina et al. 2008), MassMov2D (Beguería et al. 2009), RASH3D (Pirulli and Sorbino, 2008) and the Rapid Mass Movements RAMMS (Hussin et al., 2012).

The simplified Bingham fluid model characterizes viscous flows, and the total shear stress is the sum of a yield stress and a viscous stress (e.g., Chen and Lee, 2002; Naef et al., 2006;):

$$
S_{f}=1.5 \cdot \frac{\tau_{y}}{\gamma \cdot h}+\frac{3 \cdot \mu_{B} \cdot u}{\gamma \cdot h^{2}}
$$

where $\mu_{B}$ is the Bingham viscosity, $\square$ is the specific weight of the fluid-solid mixture, $\tau_{y}$ is the yield stress, $h$ is the flow depth, and $u$ the flow velocity. Sediment-laden flows have also been modelled using the Manning equation (Hungr, 1995; Naef et al., 2006):

$$
S_{f}=\frac{n^{2} \cdot u^{2}}{h^{4 / 3}}
$$

Where $n$ is the Manning roughness coefficient. Another model for debris flows is FLO2D (O`Brien et al., 1993), one of the first models commercially available, and it combines several of the previous rheological approaches.

The three approaches shown in equations 1,2 and 3 were used here in a first attempt to reproduce, by numerical modelling, the flow front of some of the WLF observed in the videos. Three cases were selected for this modelling exercise, Kelly Creek (Australia), North Creek (USA), and the Pocuro stream (Chile). The aim of the simulations was to estimate a range of parameters that fit with the observed WLFs, but also to better understand the mechanics of such flows. For each case, the following information extracted from the videos was used as input data: the longitudinal channel slope, the flow front velocity and the flow depth of the flow front at two time-steps, which gave us the flow surface profile. Using the profile of the front 
(characterized by the flow depth and flow velocity) at the first time step as the initial condition, and tuning the rheological model parameters, we reproduced numerically the flow profile at the second time step (assuming that the front velocity is constant along the simulation). We have used Iber (Bladé et al., 2014), a two-dimensional numerical modelling tool for simulating free surface flows. Iber was initially developed to perform hydrodynamic and sediment transport simulations, but was later coupled to different modules such as the wood transport module (Ruiz-Villanueva et al., 2014) or the wet snow avalanches module (Torralba et al., 2017). Iber solves the Shallow Water Equations in conservative form using the Finite Volume Method. For water, the shear stress terms of the equations are represented with the Manning Equation, using a centred discretizational and a semimplicit time advancing scheme. For snow avalanches, Iber uses the Voellmy model, also with a centred discretization for the turbulent stress terms, but an upwind scheme for the Coulomb stresses. For the present work, Iber has been modified by adding the simplified Bingham model, but also including a pressure factor $K_{P}$ (explained later) that multiplies the pressure terms of the momentum equations. For the simulation of the three case studies, three simple models were built in Iber, one for each case, consisting of a straight channel, a mesh with one element in the channel width and a mesh size of $0.1 \mathrm{~m}$ along the channel, and no lateral friction.

Simulation results showed that the hypercongested flow front could be reproduced with the three approaches and with different combinations of the different parameters involved in the governing equations (Fig. S3 to S8). In order to keep the flow front velocity constant, the parameters $\square$ and $\tau_{y}$ used in the Voellmy and Bingham models, respectively, were assumed equal zero, because, in the Voellmy model, if the bed slope is lower than the value of $\square \square$ the flow stops. However, although the slope of the bed was relatively low in some of the observed cases, the WLFs were flowing, allowing us to assume a value of $\square$ equal to zero (i.e., because the WLF is a combination of wood and water, the liquid fraction does not stop unless the bed 
is horizontal). This applies to the simplified Bingham model as well, for which the term corresponding to the Coulomb or yield stresses, $\tau_{y}$, was assumed to be zero. Results also revealed that, with the previous models (simplified Bingham and Voellmy), in order to properly reproduce the shape of the front, the flow velocity upstream needed to be reduced, or even stopped (unrealistic). However, when the flow velocity behind the front was correctly simulated, the front was accelerated in a way that was not observed in the videos (see Figures S4, S6 and S8), creating a flat and widely spread front (Fig. S3, S5 and S7). To solve this issue and better reproduce the observations, we considered an anisotropic pressure (i.e., assuming that in the WLF the horizontal pressure distribution can be different than the vertical pressure). To consider the anisotropy of the pressure distribution, the terms corresponding to horizontal pressure stresses in the momentum equations were corrected with a parameter $K p$ :

$$
K_{p}=\frac{\sigma_{h}}{\sigma_{z}}
$$

where $\sigma_{h}$ is the horizontal normal stress (pressure) and $\sigma_{z}$ is the vertical normal stress (hydrostatic pressure). Similar factors have been proposed for simulating other sediment-laden flows (Hungr, 1995; Pirulli et al., 2007; Hungr and McDougall, 2009) and snow avalanches (Bartelt and Gruber, 1999) .

With such a correction, the shape of the flow front and the flow velocity were better reproduced (Fig. 7 and Fig. S3 to S8), although in some cases very small values of $K p$ had to be used (Table 2).

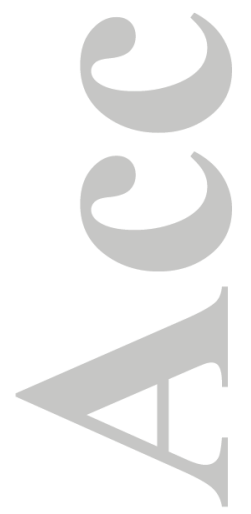



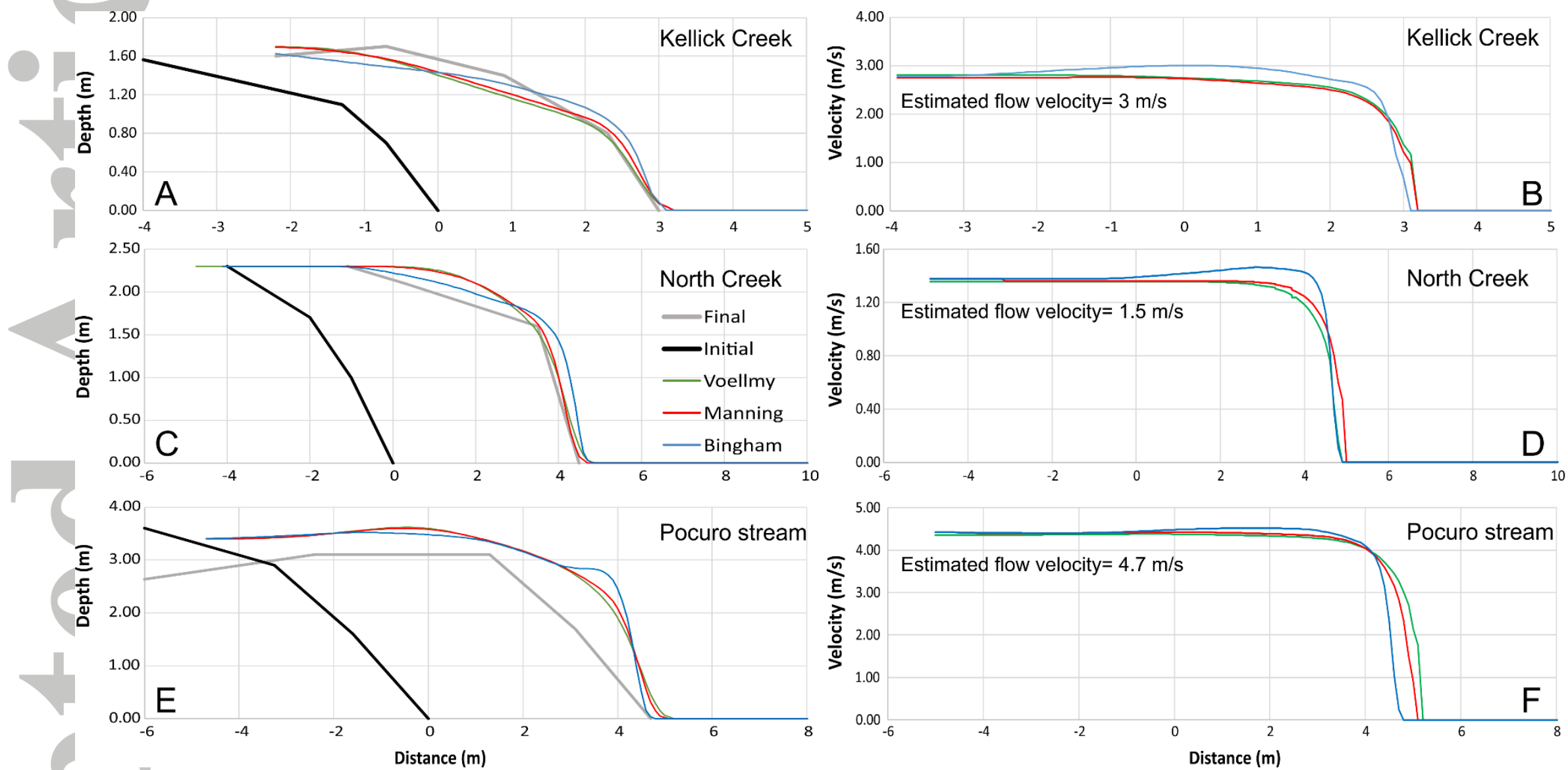

Figure 7: Simulation results, in terms of flow depth $(A, C, E)$ and flow velocity $(B, D, F)$, using three different models (i.e., simplified Bingham, Manning and Voellmy) for three case studies (A-B Kellick Creek, C-D North Creek and E-F Pocuro stream). Input data: Channel width, channel height and longitudinal slope: $8 \mathrm{~m}, 2 \mathrm{~m}$ and $0.029 \mathrm{~m} \cdot \mathrm{m}^{-1}$ for Kellick Creek respect., $7 \mathrm{~m}, 2 \mathrm{~m}$ and $0.006 \mathrm{~m} \cdot \mathrm{m}^{-1}$ for North Creek, and $21 \mathrm{~m}, 3 \mathrm{~m}$ and $0.04 \mathrm{~m} \cdot \mathrm{m}^{-1}$ for Pocuro stream. 
Figure 7 shows the selected results of the front shape and velocity for the three models (simplified Bingham, Manning and Voellmy) and the comparison with the observations. More results are provided in the supplementary material (Fig. S3 to S8). The values used for the model parameters were relatively consistent between sites (Table 2). These values were slightly different from those proposed in the literature for other flows, although closer to the range proposed for debris flows (Table 2) (Medina et al., 2008; Naef et al., 2006; Pirulli and Sorbino, 2008; Rickenmann et al., 2006; Pirulli et al., 2007) showing that WLF may have different rheological properties than other flows, and thus wood should be better considered in our understanding of flows (see Figure 6).

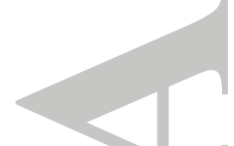

Table 2: Values used in this work and from Rickenmann, (1999); Bathurst, (1993); RAMMS User Guide; Scheidl et al., (2013) and references within for the different parameters of the three models used in the simulations

\begin{tabular}{|c|c|c|c|c|c|c|c|}
\hline Model & $\begin{array}{c}\text { Variable } \\
\text { (units) }\end{array}$ & $\begin{array}{c}\text { Kellick } \\
\text { Creek }\end{array}$ & $\begin{array}{l}\text { North } \\
\text { Creek }\end{array}$ & $\begin{array}{l}\text { Pocuro } \\
\text { stream }\end{array}$ & $\begin{array}{c}\text { Range for } \\
\text { debris } \\
\text { flows }\end{array}$ & $\begin{array}{c}\text { Range for } \\
\text { snow } \\
\text { avalanches }\end{array}$ & $\begin{array}{c}\text { Range } \\
\text { for clear } \\
\text { water }\end{array}$ \\
\hline \multirow{3}{*}{ Bingham } & $\square_{\mathrm{c}}[\mathrm{Pa}]$ & 0 & 0 & 0 & $750-3500$ & - & - \\
\hline & $\left.\square_{\mathrm{B}} \square \square \mathrm{Pa} \mathrm{s}\right]$ & 82 & 52 & 225 & $0.4-3200$ & - & - \\
\hline & $\mathrm{K}_{\mathrm{p}}[-]$ & 0.7 & 0.68 & 0.55 & $0.32-4$ & - & - \\
\hline \multirow{2}{*}{ Manning } & $\mathrm{n}\left[\mathrm{s} \cdot \mathrm{m}^{-1 / 3}\right]$ & 0.081 & 0.086 & 0.088 & $\sim 0.1$ & - & $0.02-0.2$ \\
\hline & $\mathrm{K}_{\mathrm{p}}[-]$ & 0.4 & 0.3 & 0.35 & - & - & - \\
\hline \multirow{4}{*}{ Voellmy } & $\begin{array}{c}\square \square \square \square \\
\end{array}$ & 0 & 0 & 0 & $0.1-0.55$ & $0.15-0.38$ & - \\
\hline & $\square \square\left[\mathrm{m}^{-1 / 2} / \mathrm{s}\right]$ & 188 & 178 & 172 & $10-600$ & $400-4000$ & - \\
\hline & $\mathrm{C}\left[\mathrm{s} \cdot \mathrm{m}^{-1 / 2}\right]$ & 13.7 & 13.3 & 13.1 & $3-25$ & $20-63$ & $6-45$ \\
\hline & $\mathrm{K}_{\mathrm{p}}[-]$ & 0.2 & 0.16 & 0.12 & - & - & - \\
\hline \multirow{2}{*}{$\begin{array}{c}\text { Conversion of } \\
n \text { to } \\
\text { equivalent } \mathrm{C} \\
\text { value }\end{array}$} & $\mathrm{h}[\mathrm{m}]$ & 1.6 & 2.3 & 3.4 & - & - & - \\
\hline & $\mathrm{C}=\mathrm{h}^{1 / 6} \mathrm{n}^{-1}$ & 13.4 & 13.4 & 13.9 & - & - & - \\
\hline
\end{tabular}

We believe our modelling exercise sheds light on the mechanics of WLF and opens the way to modelling WLFs, but more research and more accurate observations are needed to better calibrate and validate models that can properly reproduce complex WLF. 
The accuracy of the data extracted from the videos is limited, and these results should be taken with caution. The applied models do not consider the interaction of solid particles and the fluid: to do so, other approaches can be used, such as those proposed by Takahashi (1991), Kowalski (2008) or Armanini et al. (2009). Moreover, models used to simulate inorganic sediment-laden flows are usually validated by comparing flow velocities and runout distances (Hungr, 1995; Rickenmann et al., 2006; Pirulli and Sorbino, 2008; Scheidl et al., 2013). Here, we analysed flow front characteristics for a very short time step. Additional observations are necessary to model propagation velocities and travel distances.

An important source of information could be gathered from WLF deposits. As observed for debris flows (Costa, 1984), log levees were visible in some videos (e.g., Images F and G in Fig. S4). When the front or the congested phase of the flow occupied the entire bankfull width, such as in relatively straight single thread channels, this left characteristic deposits as log levees near the banks similar than those formed during debris flows, with pieces oriented parallel to flow along roughly the same flow-line. Levee-like deposits resulting from wood-laden flows can be identified (Figure 8) and might provide additional information on the flow propagation, but also would provide data on the occurrence of past events. Other WLF deposits can be found as jams against living standing trees along the floodplain or on alluvial fans. Identification of these deposits is still challenging, firstly because there is not a comprehensive description available, and secondly because they might not be preserved long after the event (in many cases wood is artificially removed for safety reasons). 

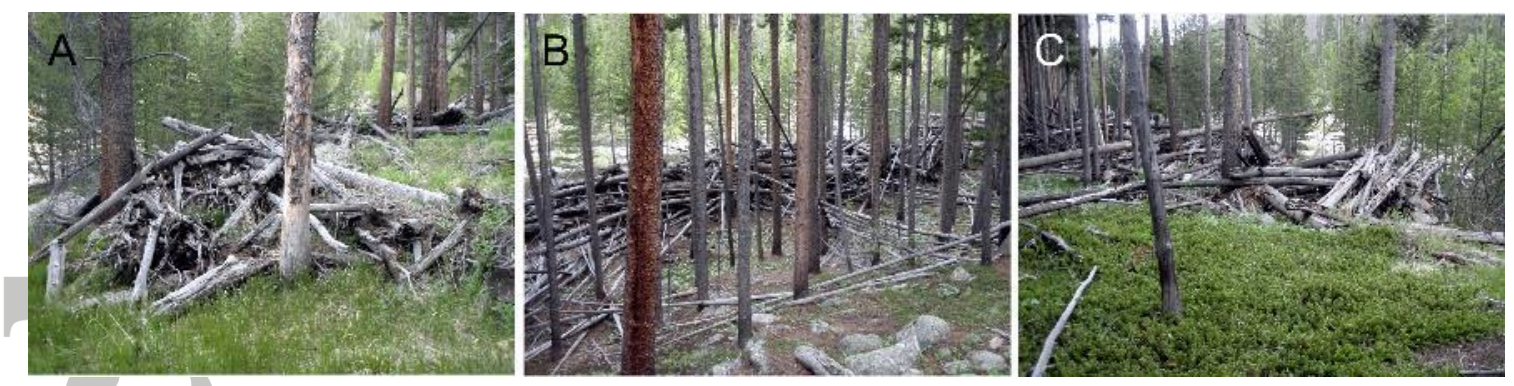

Figure 8: WLF deposits (A-C) and wood levees left by WLF (B) along the Roaring River (Rocky Mountain National Park, US), probably deposited during an outburst flood in 1982. Deposits are placed more than $10 \mathrm{~m}$ above the contemporary channel. Pictures: Ellen Wohl.

\subsection{Potential generating mechanisms of wood-laden flows}

The videos did not allow direct inference of the exact triggering or generating mechanisms for WLF, but the origin of the wood and the mechanisms responsible for generating these flows are very important. In most cases $(84 \%)$, the wood was decayed and only $16 \%$ of the events showed clearly fresh wood, as indicated by entire trees, logs with branches and leaves, or roots. This supports the hypothesis that available wood (probably a high wood load) within the channel is required to trigger hypercongested and congested woodladen flows. The timing of the flood also makes it unlikely that wood would be freshly recruited by bank erosion, for example, whereas hillslopes processes during the flood such as landslides or debris flows may still supply fresh wood

We hypothesize that WLF may be naturally generated by several cascading processes that both generate high wood loading and WLF formation and propagation. (1) a large amount of natural wood deposits within the channel or the catchment available for entrainment and transport during a flash flood or debris flow. Manmade wood, for example from clear cutting activities, could be also an important source of wood, as happened recently in New Zeeland (see https://www.stuff.co.nz/national/104486938/tolaga-bay-to-be-hit-by-more-rain-after-severeflooding); (2) a wood jam or raft breaching, in which a large wood jam collapses and delivers 
substantial wood that is then transported downstream; (3) an episodic input of woody material from a landslide or debris flow, or a tributary (Wohl et al., 2012), or other processes, such as intense windstorms, tornadoes, hurricanes (Phillips and Park, 2009), or ice breaking (Kramer et al 2017; Boivin et al 2017). A fire before the flood is mentioned in the metadata for the July 2017 flood in Payson, Arizona (USA), in which 9 persons died. A fire could have influenced the response of the catchment and the formation of the wood-laden flow; (4) a jökulhlaup or a glacial lake outburst flood (GLOF), causing substantial bank erosion and wood recruitment or supply along its route (Oswald and Wohl, 2008), although none of the sites where the videos were recorded are glaciated; (5) In high-elevation (alpine) regions another possible input process are snow avalanches (both wet and powder snow avalanches) as they can significantly damage the forest (Feistl et al., 2015) and deliver wood to streams (Lee and Benda, 2003); (6) lahars or flows developed during or after volcanic eruptions may deliver large quantities of wood as well, such as occurred at Mount St. Helens or Chaitén Volcano in Chile (Lisle, 1995; Swanson and Major, 2005; Swanson et al., 2013; Ulloa et al., 2015). But, none of the studied sites are located near volcanos; (7) tsunami waves can erode, transport and deposit significant amounts of sediments (Goto et al., 2007; Paris et al., 2010) and could also transport large amounts of wood.

The presence of a narrow section upstream from the video sites in the main channel was observed in several cases, especially in the events from USA and Switzerland, where a gorge or narrow reach has been identified upstream from where the videos were recorded. In this morphological configuration wood might be retained during other high flows because of a backwater effect, and with a high enough flood magnitude and fast rising limb on the flood hydrograph this wood might be suddenly released during subsequent floods. However, the exact mechanism of the formation of the wood-laden flows analysed in this study would require further research. In general, each of these potential triggering scenarios requires a substantial 
amount of wood within the channel (i.e., high wood loading) that can be abruptly mobilized by rapidly rising flood waters. In the absence of an abrupt increase in stage or discharge, congested wood flow may form (Kramer et al., 2017), but probably not hypercongested wood flow.

The spatial and temporal scales of wood recruitment to the channel and transport downstream depend on flood variations, the forest cover, and the channel and wood characteristics (Kramer and Wohl, 2016; Steeb et al 2017). However, due to local and/or regional variability of these variables, how and where wood comes from during an extreme event remain largely unknown. Although recruitment processes such as bank erosion can be directly observed and quantified, it is not so easy to determine the frequency and magnitude of infrequent events (Hassan et al., 2005). In a large river, Piégay et al. (2016) observed that wood is not necessarily transported directly from its recruitment sites. Kramer et al. (2017) argued that wood transport is strongly related to the amount of wood in storage from antecedent floods because past events can change the position of wood along the river corridor, yielding a wood load more available to be transported during infrequent events.

Still, predicting the development and propagation of WLF is very challenging. For these reasons, WLF should be monitored more closely to understand whether there is a consistent recurrence interval or whether they are unpredictable, as commonly supposed.

\subsection{Implications for hazards and river management}

Over the last few decades, forest cover has generally increased in many regions (Nakamura et al., 2017) because of widespread abandonment of agricultural surfaces and changes in farming practices. A natural increase in wood supply and entrainment to rivers can be expected in the near future and, together with wood augmentation for river restoration (Roni et al., 2014), may result in more frequent and widely distributed WLF. Therefore, river 
managers may need to deal with these processes more often, and the work described here may provide a basic understanding of WLF characteristics required to design clear management strategies.

WLF might be powerful agents of morphodynamic change in river corridors and can pose grave hazards to people and property, as evidenced by past events in which the transport of wood during floods and debris flows enhanced the negative consequences of such events (Ruiz-Villanueva et al., 2013, 2014c; Comiti et al., 2016; Ravazzolo et al., 2017; Steeb et al., 2017).

River and flood hazard management needs to know whether a river has the capacity to form and propagate WLF, and thereby cause hazards (Fig. S5) and potential impacts on the ecosystem (Swanson et al., 1998). In the case of WLF, wood transport rate or capacity can be defined as the amount of wood that can be moved through a given width of flow in a given time (similar to sediment capacity; Wainwright et al., 2015). The estimation of this rate is very challenging and after decades of studying debris flows and sediment transport, different equations still provide different bedload-transport rates under the same hydraulic and morphological conditions (Barry et al., 2008). Different approaches have been used to identify wood source areas and to estimate supplied wood volume (Mazzorana et al., 2009; Rigon et al., 2012; Ruiz-Villanueva et al., 2014b), but investigation is still needed to predict wood transport capacity and wood transport rates.

Few integral flood risk management strategies explicitly consider organic load (Sabo, 2000; Mazzorana et al., 2009; Wohl et al., 2016), and the effectiveness of risk mitigation critically depends on process understanding (Mazzorana et al., 2017). Results shown here might be very useful for the design of retention structures, such as racks, nets or retention basins (Piton and Recking, 2015; Hashimoto et al., 2016; Lewis and Park, 2018), which should be designed considering the flow types illustrated in Fig. 6. However, a sound flood risk 
assessment should be holistic and catchment-based, such as so-called natural flood management (NFM; Lane et al., 2017)that includes non-structural measures. Thus, we call for a systematic monitoring of WLF worldwide. Pioneering work in monitoring wood transport (MacVicar et al., 2009; MacVicar and Piégay, 2012; Kramer and Wohl, 2014;Benacchio et al., 2017) proved that time lapse photography and video cameras provide useful information, as shown also in this study.

\section{Conclusions}

We described and characterized WLFs, a commonly overlooked phenomenon that has rarely been analyzed. Here, we better define and characterize wood transport regimes, key WLF variables, such as velocity or relationship with water discharge, and the catchments and streams where they may form and propagate. We proposed novel conceptual models to better integrate wood into our understanding of flow phenomena and attempted to model WLF using singlephase flow modelling approaches. Our work opens doors to researchers, managers and stakeholders to investigate the dynamics, triggering and propagation of wood-laden flows. Therefore, we encourage the development of monitoring techniques, flume and field experiments to develop and validate numerical models that contribute to a better understanding of flows in general and eventually to better management and assessment of socio-economic and environmental impacts triggered by these processes. 


\section{Acknowledgements}

This work was supported by the WoodFlow project funded by the Swiss Federal Office for the Environment (FOEN). Bruno Mazzorana has been supported by the Iniciativa Científica Milenio (ICM) through grant NC160025 "Millennium Nucleus CYCLO The Seismic Cycle Along Subduction Zones". Diego Ravazzolo was supported by the Postdoc Chilean project Fondecyt 3170011. We are grateful to all the people who made the videos available, and those who replied our request for permission and additional data. Especial thanks to Tony and Jo O'Brien, Robert Edward Smith (Merriwa NSW, Australia) for all the information, data and pictures they sheared related to the flood in Kellick Creek in 2007; also, thanks to Storyful.com, Annemarie Gilsenan, jukinmedia.com and David O. Rankin (rankinstudio.com) for giving permission to use their videos. We thank also Giulio Calvani and Pina Nicoletta de Cicco (University of Florence, Italy) for shearing the video and information from Italy and Evelyn Coleman and Albin Schmidhauser (Canton Bern and Luzern respectively, Switzerland) for the videos and information about flood in Switzerland. We acknowledge the help of Niccolo Galatiotto (University of Bern, Switzerland) during one field survey in the Zulg River (Switzerland). Gordon Grant (US Forest Service), Frederick Swanson (USDA Forest Service), Thomas Lisle (USDA Forest Service) and Quinn Lewis (University of Illinois) provided useful comments on an earlier version of this manuscript. Comments from two anonymous reviewers significantly improved the final version of the manuscript. The data used are listed in the references, tables, and supplements. 


\section{References}

Aagaard T, Hughes M. 2013. Sediment Transport. in DJ Sherman (ed.), Reference Module in Earth Systems and Environmental Sciences: Treatise on Geomorphology: Coastal Geomorphology. 10: 74-105. DOI:10.1016/B978-0-12-374739-6.00273-6

Armanini A, Fraccarollo L, Rosatti G. 2009. Two-dimensional simulation of debris flows in erodible channels. Comput. Geosci. 35: 993-1006.

Barry JJ, Buffington JM, Goodwin P, Asce M, King JG, Emmett, WW. 2008. Performance of bed-load transport equations relative to geomorphic significance: predicting effective discharge and its transport rate. Journal of Hydraulic Engineering 134(5): 601-615.

Bartelt P, Salm B, Gruber U. 1999. Calculating dense snow avalanche runout using a Voellmyfluid model with active/passive longitudinal straining. J. Glaciol., 45(150), 242-254.

Bathurst JC. 1993. Flow resistance through the channel network. In K. Beven \& M. J. Kirkby (eds), Channel Network Hydrology, 69-98, John Wiley, New York.

Benacchio V, Piégay H, Buffin-bélanger T, Vaudor L. 2017. A new methodology for monitoring wood fluxes in rivers using a ground camera: Potential and limits. Geomorphology 279: 44-58. DOI:10.1016/j.geomorph.2016.07.019

Bladé E, Cea L, Corestein G, Escolano E, Puertas J., Vázquez-Cendón E, Dolz J, Coll A. 2014. Iber-River modelling simulation tool. Revista Internacional de Metodos Numericos para Calculo y Diseno en Ingenieria, 30(1).

Bocchiola D, Catalano F, Menduni G, Passoni G. 2002. An analytical-numerical approach to the hydraulics of floating debris in river channels. Journal of Hydrology 269(1-2): 65-78. DOI:10.1016/S0022-1694(02)00195-6

Braudrick CA, Grant GE. 2000. When do logs move in rivers?. Water Resources Research 36(2): 571-583. DOI:10.1029/1999WR900290

Braudrick CA, Grant GE, Ishikawa Y, Ikeda H. 1997. Dynamics of wood transport in streams : a flume experiment. Earth Surf. Process. Landforms 22: 669-683.

Carter RM. 1975. A discussion and classification of subaqueous mass-transport with particular application to grain-flow, slurry-flow, and fluxoturbidites. Earth Sci. Rev. 11: 145-177. DOI:10.1016/0012-8252(75)90098-7

Chen H, Hu K, Cui P, Chen X. 2017. Investigation of vertical velocity distribution in debris flows by PIV measurement. Geomatics, Nat. Hazards Risk 8. DOI:10.1080/19475705.2017.1366955

Chen H, Lee CF. 2002. Runout Analysis of Slurry Flows with Bingham Model. Journal of Geotechnical and Geoenvironmental Engineering 128(12): 1032-1042. DOI: 10.1061/(ASCE)1090-0241(2002)128:12(1032)

Comiti F, Lucía A, Rickenmann D. 2016. Large wood recruitment and transport during large floods : a review. Geomorphology 15: 23-39. DOI:10.1016/j.geomorph.2016.06.016

Costa JE, Williams GP. 1984. Debris-flow dynamics (video-tape), U.S. Geol. Surv. Open File Rep. 84-606, 22 min.

Coussot P, Meunier M. 1996. Recognition, classification and mechanical description of debris flows. Earth-Science Rev. 40: 209-227. DOI:10.1016/0012-8252(95)00065-8

Cruden DM, Varnes DJ. 1996. Landslides: investigation and mitigation. Chapter 3-Landslide types and processes. Transp. Res. board Spec. Rep. 247: 36-75.

Delannay R, Valance A, Mangeney A, Roche O, Richard P. 2017. Granular and particle-laden flows: from laboratory experiments to field observations. J. Phys. D. Appl. Phys. 50, 53001. 40 pp. DOI:10.1088/1361-6463/50/5/053001

Feistl T, Bebi P, Christen M, Margreth S, Diefenbach L, Bartelt P. 2015. Forest damage and snow avalanche flow regime Nat. Hazards Earth Syst. Sci. 15: 1275-1288. DOI:10.5194/nhess-15-1275-2015 
Gilbert GK. 1914. The transport of debris by running water. U.S. Geol. Surv. Prof. Pap. 86: 1263.

Goto K, Chavanich SA, Imamura F, Kunthasap P, Matsui T, Minoura K, Sugawara D, Yanagisawa H. 2007. Distribution, origin and transport process of boulders deposited by the 2004 Indian Ocean tsunami at Pakarang Cape, Thailand, Sediment. Geol. 202: 821837.

Guillén NF, Patalano A, García CM, Bertoni JC. 2017. Use of LSPIV in assessing urban flash flood vulnerability. Natural Hazards, 87(1): 383-394. DOI:10.1007/s11069-017-2768-8

Gurnell A.M. 2007. Analogies between mineral sediment and vegetative particle dynamics in fluvial systems. Geomorphology 89: 9-22. DOI:10.1016/j.geomorph.2006.07.012

Gyr A, Hoyer K. 2006. Sediment Transport A Geophysical Phenomenon. Springer International Publishing. DOI:10.1016/0096-3003(97)90009-6

Hashimoto H, Hashimura K, Nagano H. 2016. Experimental Investigation into Flow Behavior of Wood-Sediment-Water Mixture at a Grid Type of Open Check Dam. International Journal of Erosion Control Engineering 9: 188-193.

Hassan MA, Church M, Lisle TE, Brardinoni F, Benda L, Grant GE. 2005. Sediment Transport and Channel Morphology of Small, Forested Streams 1. J. Am. Water Resour. Assoc. 41: 853-876. DOI:10.1111/j.1752-1688.2005.tb03774.x

Hinderer M, Kastowski M, Kamelger A, Bartolini C, Schlunegger F. 2013. River loads and modern denudation of the Alps - A review. Earth-Science Rev. 118: 11-44. DOI:10.1016/j.earscirev.2013.01.001

Hungr O, Evans SG, Bovis MJ, Hutchinson JN. 2001. A review of the classification of landslides of the flow type. Environmental \& Engineering Geoscience 7: 221-238.

Hungr O, McDougall S. 2009. Two numerical models for landslide dynamic analysis. Computers \& Geosciences 35: 978-992.

Hungr O. 1995. A model for the runout analysis of rapid flows slides, debris flows, and avalanches. Canadian Geotechnical Journal 32(4): 610-623.

Iverson RM, Ouyang C. 2015. Entrainment of bed material by Earth-surface mass flows: Review and reformulation of depth-integrated theory. Reviews of Geophysics 53: 1-32. DOI:10.1002/2013RG000447

Iverson RM. 1997. The physics of debris flows. Rev. Geophys. 35: 245-296. DOI:10.1029/97RG00426

Iverson RM. 2003. The debris-flow rheology myth, in Debris-flow Hazards Mitigation: Mechanics, Prediction, and Assessment, v. 1, D. Rickenmann and C.L. Chen, eds., Millpress, Rotterdam, 303-314.

Iverson RM. 2013. Mechanics of debris flows and rock avalanches. In: Harindra Joseph Fernando (Ed.), Handbook of environmental fluid dynamics, Volume One. Taylor and Francis Group LLC. ISBN: 978-1-4398-1669-1.

Iverson RM. 2014. Debris flows: behaviour and hazard assessment. Geology Today 30(1): 1520.

Jha SK. 2017. Fluids Effect of particle inertia on the transport of particle-laden open channel flow. Eur. J. Mech. B/Fluids 62: 32-41. DOI:10.1016/j.euromechflu.2016.10.012.

Kondolf GM, Lisle TE, Wolman GM. 2005. Bed Sediment Measurement. Tools in Fluvial Geomorphology. DOI:10.1002/0470868333.ch13

Kowalski J. 2008. Two-phase modelling of debris flows. Ph.D. thesis, ETH Zürich, Dissertation, ETH No. 17827, p 135.

Kramer N, Wohl E. 2014. Estimating fluvial wood discharge using time-lapse photography with varying sampling intervals. Earth Surf. Process. Landforms 852: 844-852. DOI:10.1002/esp.3540

Lancaster ST, Hayes SK, Grant GE. 2003. Effects of wood on debris flow runout in small 
mountain watersheds. Water Resour. Res. 39(6): 1168. DOI:10.1029/2001WR001227

Lane SN, Bakker M, Gabbud C, Micheletti N, Saugy JN. 2017. Sediment export, transient landscape response and catchment-scale connectivity following rapid climate warming and Alpine glacier recession. Geomorphology 15: 210-227. DOI:10.1016/j.geomorph.2016.02.015

Le Boursicaud R, Pénard L, Hauet A, Thollet F, Le Coz J. 2016. Gauging extreme floods on YouTube: Application of LSPIV to home movies for the post-event determination of stream discharges. Hydrol. Process. 30: 90-105. DOI:10.1002/hyp.10532

Lewis QW, Park E. 2018. Volunteered Geographic Videos in Physical Geography: Data Mining from YouTube. Annals of the American Association of Geographers 108(1): 52 70. DOI:10.1080/24694452.2017.1343658

Lisle TE. 1995. Effects of Coarse Woody Debris and its Removal on a Channel Affected by the 1980 Eruption of Mount St. Helens, Washington. Water Resour. Res. 31: 1797-1808. DOI:10.1029/95WR00734

Lisle TE. 2002. How Much Dead Wood in Stream Channels is Enough? USDA Forest Service Technical Report PSW-GTR-181: 85-93.

Macvicar B, Piégay H. 2012. Implementation and validation of video monitoring for wood budgeting in a wandering piedmont river, the Ain River (France), Earth Surf. Process. Landforms 37: 1272-1289. DOI:10.1002/esp.3240

Macvicar BJ, Henderson A, Comiti F, Oberlin C, Pecorari E. 2009. Quantifying the temporal dynamics of wood in large rivers: field trials of wood surveying, dating, tracking, and monitoring techniques. Earth Surf. Process. Landforms 34: 2031-2046. DOI:10.1002/esp.1888

May CL. 2002. Debris flows through different forest age classes in the Central Oregon Coast Range. Journal of the American Water Resources Association 38: 1097-1113. DOI:10.1111/j.1752-1688.2002.tb05549.x

Mazzorana B, Hübl J, Zischg A, Largiader A. 2011. Modelling woody material transport and deposition in alpine rivers. Natural Hazards 56(2): 425-449. DOI:10.1007/s11069-0099492-y

Māzzorana B, Ruiz-Villanueva V, Marchi L, Cavalli M, Gems B, Gschnitzer T, Mao L, Iroumé A, Valdebenito G. 2017. Assessing and mitigating large wood-related hazards in mountain streams: recent approaches. J. Flood Risk Manag. 11: 207-222. DOI:10.1111/jfr3.12316

Mazzorana B, Zischg A, Largiader A, Sciences AL, Hübl J. 2009. Hazard index maps for woody material recruitment and transport in alpine catchments. Nat. Hazards Earth Syst. Sci. 9: 197-209. DOI:10.5194/nhess-9-197-2009

McDougall S, Hungr O. 2005. Dynamic modelling of entrainment in rapid landslides. Canadian Geotechnical Journal 42: 1437-1448.

Naef D, Rickenmann D, Rutschmann P, Mcardell BW. 2006. Comparison of flow resistance relations for debris flows using a one-dimensional finite element simulation model. Nat. Hazards Earth Syst. Sci. 6: 155-165.

Nakagawa H, Takahashi T, Ikeguchi M. 1994. Driftwood behavior by overland flood flows. J Hydrosci Hydraul Eng JSCE 12: 31-39.

Nakamura F, Seo J Il, Akasaka T, Swanson FJ. 2017. Large wood, sediment, and flow regimes: Their interactions and temporal changes caused by human impacts in Japan. Geomorphology 279: 176-187. DOI:10.1016/j.geomorph.2016.09.001

O'Brien JS, Julien PY, Fullerton WT. 1993. Two-dimensional water flood and mudflow simulation, J. Hydrol. Eng. 119(2): 244-261.

Oswald EB, Wohl E. 2008. Wood-mediated geomorphic effects of a jökulhlaup in the Wind River Mountains, Wyoming. Geomorphology 100: 549-562. DOI:10.1016/j.geomorph.2008.02.002 
Paris R, Fournier J, Poizot E, Etienne S, Mortin J, Lavigne F, Wassmer P. 2010. Boulder and fine sediment transport and deposition by the 2004 tsunami in LhokNga (western Banda Aceh, Sumatra, Indonesia), A coupled offshore-onshore model. Mar. Geol. 268: 43-54.

Paul JD, Buytaert W, Allen S, Ballesteros-Cánovas, JA, Bhusal J, CieslikK, Clark J, Dugar S, Hannah DM, Stoffel M, Dewulf A, Dhital MR, Liu W, Nayaval JL. 2017. Citizen science for hydrological risk reduction and resilience building. Wiley Interdisciplinary Reviews: Water 5: 1-15. DOI:10.1002/wat2.1262

Peel MC, Finlayson BL, McMahon TA. 2007. Updated world map of the Köppen-Geiger climate classification. Hydrol. Earth Syst. Sci. 11: 1633-1644. DOI:10.5194/hess-111633-2007

Persi E, Petaccia G, Sibilla S. 2017. Woody debris transport modelling by a coupled DE-SW approach. Nat. Hazards. DOI:10.1007/s11069-017-2891-6

Phillips CJ, Davies TRH. 1991. Determining rheological parameters of debris flow material. Geomorphology 4(2): 101-110. DOI:10.1016/0169-555X(91)90022-3

Phillips JD, Park L. 2009. Forest blowdown impacts of Hurricane Rita on fluvial systems. Earth Surf. Process. Landforms 34: 1069-1081. DOI:10.1002/esp.1793.

Pierson TC, Costa JE. 1987. A rheologic classification of subaerial sediment-water flows. In: GSA Reviews in Engineering Geology Debris Flows/Avalanches. John E. Costa, Gerald F. Wieczorek (Ed.), Geological Society of America, Volume 7. DOI:https://doi.org/10.1130/REG7

Pirulli M, Bristeau M, Mangeney A, Scavia C. 2007. The effect of the earth pressure coefficients on the runout of granular material. Environ. Model. Software 22: 1437-1454. DOI:10.1016/j.envsoft.2006.06.006

Pirulli M, Sorbino G. 2008. Assessing potential debris flow runout: a comparison of two simulation models. Nat. Hazards Earth Syst. Sci. 8: 961-971. DOI: 10.5194/nhess-8-9612008

Piton G, Recking A. 2015. Design of Sediment Traps with Open Check Dams. II: Woody Debris. J. Hydraul. Eng. 142. DOI:10.1061/(ASCE)HY.1943-7900.0001049

Prochaska A, Santi P, Higgins J, Cannon S. 2008. A study of methods to estimate debris flow velocity. Landslides 5(4): 431-444. DOI10.1007/s10346-008-0137-0

Ravazzolo D, Mao L, Mazzorana B, Ruiz-Villanueva V. 2017. Brief communication: The curious case of the large wood-laden flow event in the Pocuro stream (Chile). Nat. Hazards Earth Syst. Sci. 17: 2053-2058. DOI: 10.5194/nhess-17-2053-2017.

Rickenmann D. 1999. Empirical relationships for debris flows. Natural Hazards 19: 47-77.

Rickenmann D. 2017. Sediment transport. In J. Aberle, C. D. Rennie, D. M. Admiraal, and M. Muste (Eds.), Experimental hydraulics. Methods, instrumentation, data processing and management. Vol II: instrumentation and measurement techniques (pp. 261-307), Boca Raton: CRC Press.

Rickenmann D. 2016. Methods for the quantitative assessment of channel processes in torrents (steep streams). International Association for Hydro-Environment Engineering And Research IAHR Monograph. Taylor \& Francis Group, London, UK. CRC Press.

Rickenmann D, Laigle D, McArdell BW, Hübl J, 2006. Comparison of 2D debris-flow simulation models with field events. Comput. Geosci. 10: 241-264. DOI:10.1007/s 10596005-9021-3

Rigon E, Comiti F, Lenzi MA. 2012. Large wood storage in streams of the Eastern Italian Alps and the relevance of hillslope processes. Water Resour. Res. 48: W01518. DOI:10.1029/2010WR009854

Roni P, Beechie T, Pess GR, Hanson K. 2014. Wood placemment in river restoration: Fact, fiction and future direction. Can. J. Fish. Aquat. Sci. 72: 466-478. DOI:10.1139/cjfas2014-0344 
Roth DL, Brodsky EE, Finnegan NJ, Rickenmann D, Turowski JM, Badoux A. 2016. Bed load sediment transport inferred from seismic signals near a river. Journal of Geophysical Research: Earth Surface 121: 725-747. DOI:10.1002/2015JF003782.

Ruiz Villanueva V, Bladé Castellet E, Díez-Herrero A, Bodoque JM, Sánchez-Juny M. 2014c. Two-dimensional modelling of large wood transport during flash floods. Earth Surf. Process. Landforms 39: 438-449. DOI:10.1002/esp.3456

Ruiz-Villanueva V, Bladé E, Sánchez-Juny M, Marti-Cardona B, Díez-Herrero A, Bodoque JM. 2014a. Two-dimensional numerical modeling of wood transport. Journal of Hydroinformatics 16(5): 1077-1096. DOI:10.2166/hydro.2014.026

Ruiz-Villanueva V, Bodoque JM, Díez-Herrero A, Eguibar MA, Pardo-Igúzquiza E. 2013. Reconstruction of a flash flood with large wood transport and its influence on hazard patterns in an ungauged mountain basin. Hydrol. Process. 27: 3424-3437. DOI:10.1002/hyp.9433

Ruiz-Villanueva V, Díez-Herrero A, Ballesteros-Canovas JA, Bodoque JM. 2014b. Potential large woody debris recruitment due to landslides, bank erosion and floods in mountain basins: a quantitative estimation approach. River Research and Applications 30: 81-97. DOI:10.1002/rra.

Ruiz-Villanueva V, Galatiotto N, Bürkli L, Stoffel M. 2017. Understanding triggers and dynamics of wood-laden flash floods in mountain catchments : examples from the Zulg River (Switzerland), Geophysical Research Abstracts, European Geoscience Union (EGU) Vol. 19, EGU2017-16792, Viena, Austria.

Ruiz-Villanueva V, Piégay H, Gurnell AA, Marston RA, Stoffel M. 2016. Recent advances quantifying the large wood dynamics in river basins: New methods and remaining challenges. Rev. Geophys. 54. DOI:10.1002/2015RG000514.

Ruiz-Villanueva V, Wyzga B, Mikuś P, Hajdukiewicz H, Stoffel M. 2016. The role of flood hydrograph in the remobilization of large wood in a wide mountain river. J. Hydrol. 541: 330-343. DOI:10.1016/j.jhydrol.2016.02.060

Sabo Department, Ministry of Construction, Japan. 2000. Guideline for driftwood countermeasures. Guideline of Ministry of Construction, Japan (http://www.saboint.org/guideline/pdf/driftwoodCountermeasure Guideline.pdf, online accessed on 20 March 2018).

Scheidl C, Rickenmann D, McArdell BW. 2013. Runout prediction of debris flows and similar mass movements. In: C. Margottini, P. Canuti \& K. Sassa (eds.), Landslide Science and Practice. Springer 3: 221-229. DOI:10.1007/978-3-642-31310-3_30

Shimizu Y, Osada K, Takanashi T. 2006. Numerical Simulation Of The Driftwoods Behavior By Using A Dem-Flow Coupling Model. Proceedings of Hydraulic Engineering (Japan Society of Civil Engineers) 50: 787-792. (written in Japanese with English Abstract).

Shrestha BB, Nakagawa H, Kawaike K, Baba Y, Zhang H. 2009. Numerical Simulation on Debris-Flow With Driftwood and Its Capturing Due To Jamming of Driftwood on a Grid Dam. Annual Journal of Hydraulic Engineering 53: 169-174.

Shrestha BB, Nakagawa H, Kawaike K, Baba Y, Zhang H. 2012. Driftwood deposition from debris flows at slit-check dams and fans. Natural Hazards 61(2): 577-602. DOI:10.1007/s 11069-011-9939-9

Steeb N, Rickenmann D, Badoux A, Rickli C, Waldner P. 2017. Large wood recruitment processes and transported volumes in Swiss mountain streams during the extreme flood of August 2005. Geomorphology 279: 112-127. DOI:10.1016/j.geomorph.2016.10.011

Swanson FJ, Johnson SL, Gregory SV, Acker SA. 1998. Flood Disturbance in a Forested Mountain Landscape: Interactions of land use and floods. BioScience 48: 681-689. DOI:10.2307/1313331

Swanson FJ, Lienkaemper W. 1978. Physical consequences of large organic debris in pacific 
northwest streams. USDA For. Serv. Gen. Tech. Rep. 17.

Swanson FJ, Jones JA, Crisafulli CM, Lara A. 2013. Effects of volcanic and hydrologic processes on forest vegetation: Chaitén Volcano, Chile. Andean Geol. 40. DOI:10.5027/andgeoV40n2-a10

Swanson FJ, Major JJ. 2005. Physical events, environments, and geological-ecological interactions at Mount St. Helens: March 1980-2004. In Ecological Responses to the 1980 Eruption of Mount St. Helens. (Dale, V.H.; Swanson, F.J.; Crisafulli, C.M.; editors), Springer: 27-44. New York.

Takahashi T. 1991. Debris Flow (IAHR Monograph Series, 165 pp.). International Association for Hydraulic Research, Ecole Polytechnique Fédérale, Lausanne, Switzerland and A. A. Balkema, Rotterdam.

Torralba A, Bladé E, Oller P. 2017. Implementació d'un model numèric bidimensional per a

simulació d'allaus de neu densa. Pyrenean Symposium on Snow and Avalances, Encamp -Andorra, 54.

Tsutsumi D, Laronne JB. 2017. Gravel Bed Rivers: Processes and Disasters, Wiley Blackwell, chichester, UK.

Ulloa H, Iroumé A, Picco L, Korup O, Lenzi MA, Mao L, Ravazzolo D. 2015. Massive biomass flushing despite modest channel response in the Rayas River following the 2008 eruption of Chaitén volcano, Chile. Geomorphology 250: 397-406. DOI:10.1016/j.geomorph.2015.09.019

Wainwright J, Parsons AJ, Cooper JR, Gao P, Gillies JA, Mao L, Orford JD, Knight PG. 2015. The concept of transport capacity in geomorphology. Rev. Geophys. 53: 1155-1202. DOI:10.1002/2014RG000474

Wilkowske CD, Kenney TA, Wright SJ. 2011. Methods for estimating monthly and annual streamflow statistics at ungaged sites in Utah. Sci. Investig. Rep. 2008-5230, U.S. Dep. Inter. U.S. Geol. Surv.

Williams GP. 1989. Sediment concentration versus water discharge during single hydrologic events in rivers. J. Hydrol. 111, 89-106.Wohl, E. (2014), A legacy of absence: Wood removal in US rivers. Prog. Phys. Geogr. 38: 637-663. DOI:10.1177/0309133314548091

Wohl E, Bledsoe BP, Fausch KD, Kramer N, Bestgen KR, Gooseff MN. 2016. Management of Large Wood in Streams: An Overview and Proposed Framework for Hazard Evaluation. Am. Water Resour. Assoc. 1482. DOI:10.1017/CBO9781107415324.004.

Wohl E, Dwire K, Sutfin N, Polvi L, Bazan R. 2012. Mechanisms of carbon storage in mountainous headwater rivers. Nat. Commun. 3: 1263. DOI:10.1038/ncomms2274. 


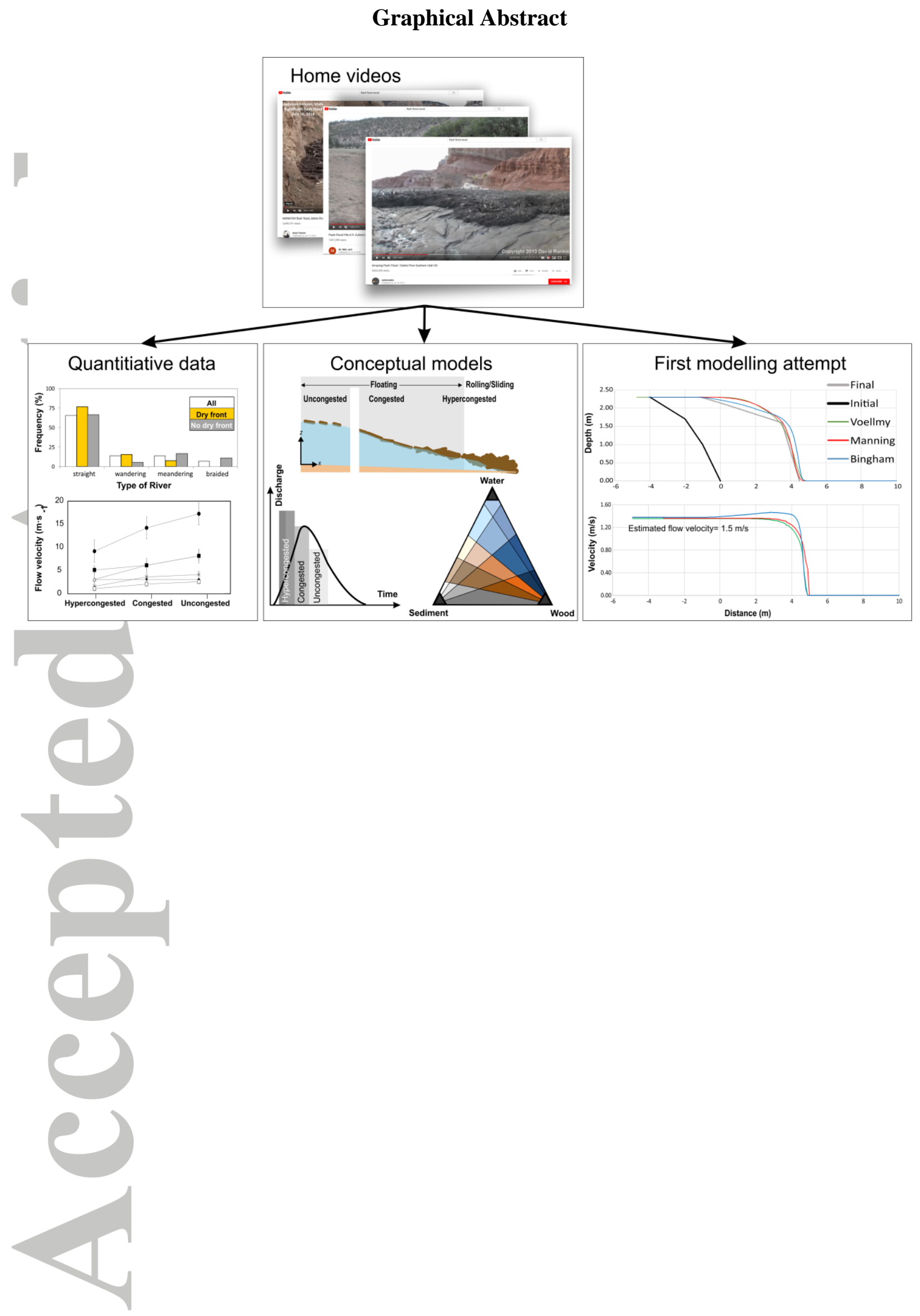

This article is protected by copyright. All rights reserved. 